\title{
Relationship Lending in Syndicated Loans: a Participant's Perspective
}

\author{
Xinlei Li
}

Submitted in partial fulfillment of the

requirements for the degree of

Doctor of Philosophy

under the Executive Committee

of the Graduate School of Arts and Sciences

COLUMBIA UNIVERSITY 
(C)2017

Xinlei Li

All rights reserved 


\begin{abstract}
Relationship Lending in Syndicated Loans: a Participant's Perspective
\end{abstract}

\title{
Xinlei Li
}

I explore the role of participants' relationships with borrowers and lead arrangers in syndicated lending. I predict and find that these relationships mitigate the information asymmetry problems faced by participants with both borrowers and lead arrangers, and allow participants to take a larger share in the loan. In particular, participants with a borrower relationship take, on average, a 10\% larger share of the loan, with the effect being more pronounced when the borrower is informationally opaque or less conservative in its accounting. Similarly, participants with a lead arranger relationship take, on average, a 9\% larger share of the loan, with the effect being more pronounced: (i) when the borrower has engaged in accounting irregularities or covenant violations in the past, (ii) when the lead arranger is a repeat lender or a large lender, and (iii) when participants have limited information acquisition capacity. Furthermore, loans with a larger total share taken by participants with a borrower or lead arranger relationship are associated with a smaller lead arranger share, less concentrated loan syndicate structure, a lower loan spread, and a lower upfront fee, consistent with these relationships mitigating information asymmetry. Overall, my study sheds light on how participant-level relationship lending shapes debt contracting. 


\section{Table of Contents}

List of Charts, Graphs, and Illustrations..................................................ii

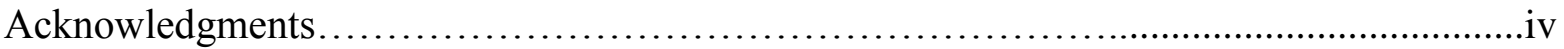

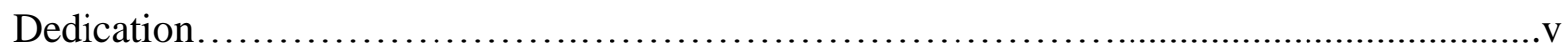

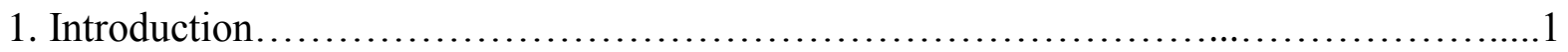

2. Institutional Background, Related Literature and Hypothesis Development.........................8

2.1. Information Asymmetry and Participant-Level Relationships in Syndicated

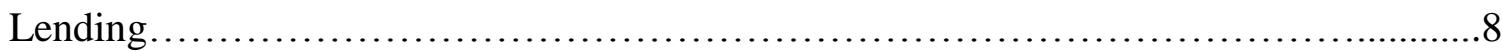

2.1.1. Cross-Sectional Predictions: Borrower Characteristics.........................12

2.1.1.1. Borrower Information Opacity ....................................12

2.1.1.2. Borrowers' Accounting Conservatism..................................14

2.1.1.3. Borrowers' Past Accounting Irregularities...............................14

2.1.1.4. Borrowers' Previous Loan Performance................................15

2.1.2. Cross-Sectional Predictions: Lead Arranger Characteristics ........................15

2.1.3. Cross-Sectional Predictions: Participant Characteristics.................................16

2.2. Participant-Level Relationships and Loan Syndicate Structure.....................17

2.3. Participant-Level Relationships and Cost of Debt.................................18

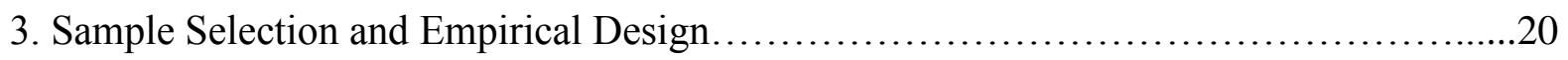

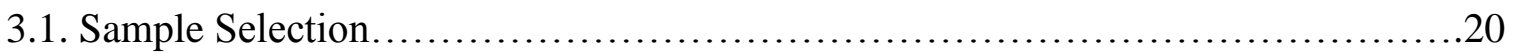


3.2. Empirical Design.

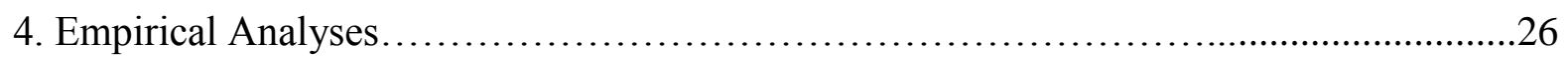

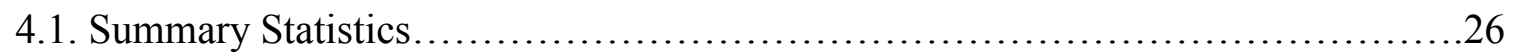

4.2. The Effect of PBR and PLR on Participants' Share in the Loan..................28

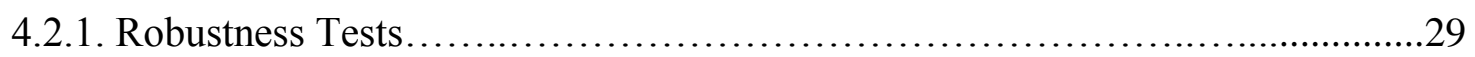

4.2.2. Cross-sectional Determinants: Borrower Characteristics .......................31

4.2.3. Cross-Sectional Determinants: Lead Arranger Characteristics...................35

4.2.4. Cross-Sectional Determinants: Participant Characteristics.....................35

4.3. Loan Syndicate Structure.............................................. 36

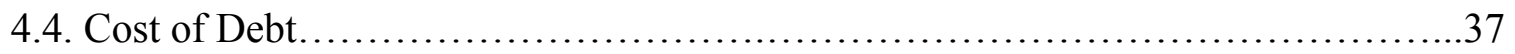

4.5. Incomplete Contracting...............................................

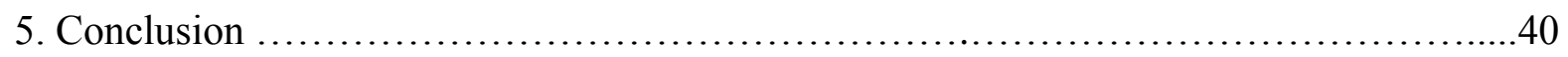

References...............................................................53 


\section{List of Charts, Graphs, and Illustrations}

Table 1: Sample Selection and Descriptive Statistics .....................................42

Table 2: The Effect of PBR and PLR on Participants' Share in the Loan ......................44

Table 3: Borrower Characteristics and the Effect of PBR and PLR on Participants' Share in

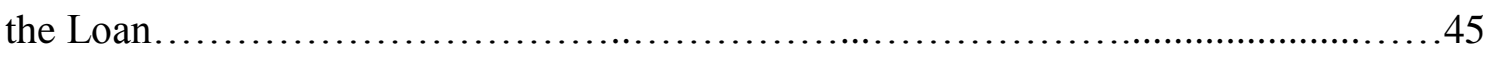

Table 4: Lead Arranger Characteristics and the Effect of PBR and PLR on Participants' Share in

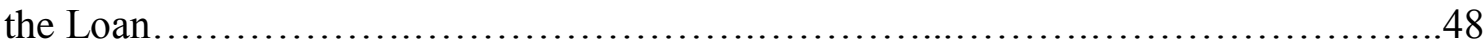

Table 5: Participant Characteristics and the Effect of PBR and PLR on Participants' Share in

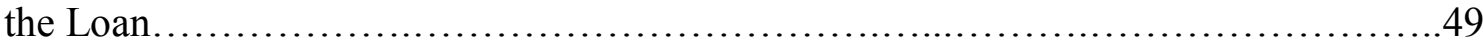

Table 6: The Effect of PBR and PLR on Loan Syndicate Structure............................50

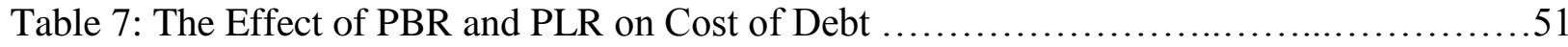

Table 8: The Effect of PBR and PLR on Incomplete Debt Contracting........................52

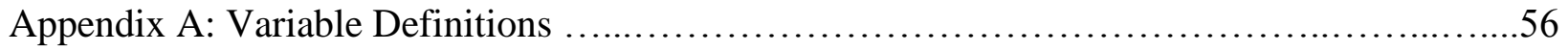

Appendix B: The Robustness Test on Total Participant Share................................58

Appendix C: The Robustness Test on PBR and PLR Measured by Outstanding Loans............59

Appendix D: The Robustness Test on PBR*PLR ....................................60

Appendix E: The Robustness Test on Relationship Intensity............................61

Appendix F: The Robustness Test on Single Facility Loans..............................62

Appendix G: PSM Robustness Tests................................................63 


\section{Acknowledgements}

I am deeply indebted to my dissertation advisor Fabrizio Ferri, whose generous guidance and support made it possible for me to finish my dissertation. It was a great pleasure working with him.

I am also grateful to my dissertation committee members Dan Amiram, Urooj Khan, Doron Nissim and Christopher Williams for their guidance and support. I would also like to thank Jonathan Glover, Trevor Harris, Alon Kalay, Christian Leuz, Regina Wittenberg-Moerman and seminar participants at Chinese University of Hong Kong, City University of Hong Kong, Columbia University, Hong Kong University of Science and Technology, Nanyang Technological University, Peking University, Santa Clara University and University of Toronto for valuable comments. I gratefully acknowledge the financial support from Columbia Business School.

Most importantly, I would like to express my deepest gratitude to my parents, who have made every effort to help me fulfill my dreams, and my fiancé, who has been a great life partner to me in good and bad days, and always reminds me how strong our love can grow when our souls grow together. 


\section{Dedication}

To my parents and fiancé 


\section{Introduction}

The syndicated loan market represents a substantial and increasing portion of capital markets. ${ }^{1}$ A syndicated loan typically involves lead arrangers, who originate and administer the loan, and participant lenders, who as a group take the majority portion of the credit balance. The nature of syndicated debt contracting results in information asymmetry not only between the participants and the borrower but also between the participants and the lead arrangers. Theory models predict that, to mitigate this information asymmetry, uninformed lenders (i.e., participants) require informed lenders (i.e., lead arrangers) to take a large share of the loan, so that informed lenders have incentives to engage in appropriate levels of due diligence and monitoring (Holmstrom 1979; Holmstrom and Tirole 1997). Consistent with the theory, empirical studies find that lead arrangers take a larger stake in loans requiring greater due diligence and monitoring (e.g., Simons 1993; Dennis and Mullineaux 2000; Lee and Mullineaux 2004; Jones et al. 2005; Sufi 2007; Amiram et al. 2016).

In this study, I focus on an additional mechanism that can help to mitigate information asymmetry, namely, participants' past relationships with the borrower and the lead arrangers. Past transactions with the same borrower provide participants with proprietary information about the borrower's risk taking, and thus help them in the assessment of the borrower's credit worthiness. Similarly, participation in past syndicates with the same lead arranger can help participants to assess the lead arranger's due diligence and monitoring ability. Thus, from a participant's perspective, a participant-borrower relationship (hereinafter PBR) helps to mitigate information asymmetry problems with the borrower, while a participant-lead arranger relationship (hereinafter PLR) helps to mitigate information asymmetry problems with the lead arranger. Hence, I predict

\footnotetext{
${ }^{1}$ In 2012, global syndicated loans raised $\$ 3.3$ trillion, more than 5 times the $\$ 0.6$ trillion raised by global equity markets. Global syndicated loans rose to 4.6 trillion in 2014 (Thomson Reuters).
} 
that these two relationships will influence loan contracting outcomes at both the participant and the loan level. In particular, I examine how PBR and PLR affect three outcomes: individual participants' share in the loan, loan syndicate structure, and cost of debt. My primary analyses focus on how PBR and PLR influence the amount of a loan an individual participant retains. Understanding the determinants of a participant's share in the loan is important because participants as a group typically take the majority share of the loan. Also, prior studies tend to treat participants as a group having identical information asymmetry problems, ignoring potential heterogeneity among participants (e.g., Holmstrom and Tirole 1997; Dennis and Mullineaux 2000). In contrast, I identify a key source of this heterogeneity - past relationships with borrowers and lead arrangers - and examine its consequences.

To conduct this investigation, I examine a sample of 5,989 loan packages between 1990 and 2012. I construct an indicator variable equal to 1 if the participant has lent to the same borrower within the past 5 years (capturing the participant-borrower relationship, PBR) and an indicator variable equal to 1 if the participant has joined a syndicate with the same lead arranger (for any borrower) within the past 5 years (capturing the participant-lead arranger relationship, PLR). ${ }^{2}$ From the previous loans with the borrower (PBR), participants get the information memorandum about the borrower before loan initiation and information updates about the borrower's credit risk after loan initiation, while from the previous loans with the lead arranger (PLR), participants obtain information about the lead arranger's loan origination and loan monitoring activities.

\footnotetext{
${ }^{2}$ PLR and PBR are independent of each other. Participants without a borrower relationship (i.e., PBR=0) can obtain a lead arranger relationship (i.e., PLR=1) from the lead arranger's prior syndicates with other borrowers, while participants without a lead arranger relationship (i.e., $P L R=0$ ) can obtain a borrower relationship (i.e., $P B R=1)$ from the borrower's prior loans originated by other lead arrangers.
} 
I predict that these relationships will reduce the information asymmetry problems faced by participants and allow them to take a larger share in the loan. Consistent with this argument, I find that participants with PBR (PLR) take a 10\% (9\%) larger share of the loan. These results hold after controlling for participant characteristics, borrower characteristics, lead arranger characteristics and loan characteristics, as well as borrower fixed effects and year fixed effects. They are also robust to measuring the intensity of PBR and PLR, rather than their presence.

Next, I examine how cross-sectional characteristics of borrowers, lead arrangers and participants affect the importance of these relationships in syndicated lending. As for borrower characteristics, I examine borrowers' information opacity, accounting conservatism, past accounting irregularities and previous loan performance. First, prior literature finds that relationship lending (i.e., the past relationship between the lead arranger and the borrower) is more valuable when opaque borrowers have less public information available (e.g., Berger and Udell 1995; Bharath et al. 2007; Khan et al. 2016). Similarly, I predict that the effect of PBR on participants' share in the loan is larger for opaque borrowers because past transactions with the same borrower endow participants with an information advantage and decrease their information asymmetry, allowing them to take a larger share in the loan. Following prior studies, I define a borrower to be informationally opaque when it is small (e.g., Petersen and Rajan 1994), not rated by credit rating agencies (e.g., Sufi 2007) or has low analyst following (e.g., Mansi et al. 2011). Consistent with my predictions, the effect of PBR on participants' share in the loan is larger by $63 \%$ for small borrowers, $35 \%$ for non-credit rated borrowers and $30 \%$ for borrowers with low analyst following (relative, respectively, to larger borrowers, rated borrowers and borrowers with high analyst following).

In addition, Erkens et al. (2014) find that relationship lending reduces lenders' demand for 
conservative accounting. Similarly, I predict that the effect of PBR on participants' share in the loan is larger for less conservative borrowers because participants' information advantage decreases their information asymmetry with such borrowers, allowing them to take a larger share in the loan. I define borrower conservatism using the firm-year level conservatism score in Khan and Watts (2009). Consistent with my predictions, the effect of PBR on participants' share in the loan is larger by $28 \%$ for loans with less conservative borrowers.

I also expect that the effect of PLR on participants' share is stronger when borrowers engaged in accounting irregularities or covenant violations in the past, because participants with a lead arranger relationship have more knowledge and trust in the lead arranger's ability to monitor such borrowers and avoid future accounting irregularities and covenant violations, allowing them to take a larger share in the loan. I examine accounting irregularities by Accounting and Auditing Enforcement Releases (AAER) and material financial statement restatements. Consistent with my predictions, the effect of PLR on participants' share in the loan is larger, respectively, by $118 \%$, $86 \%$ and $105 \%$ for borrowers with AAER, restatements and covenant violations.

As for lead arrangers' characteristics, I predict that the effect of PLR on participants' share is larger in the presence of a repeat lead arranger (i.e., when the lead arranger has a prior relationship with the borrower) and a large lead arranger (i.e., when the lead arranger is among the five largest lead arrangers in terms of market share) because they incur lower information gathering and monitoring cost and have stronger reputation incentives, allowing participants to place more value on PLR in their share decisions (i.e., the quality of PLR is higher). Indeed, I find that the effect of PLR on participants' share is larger by $67 \%$ in the presence of a repeat lead arranger and by $70 \%$ in the presence of a large lead arranger. 
Finally, with respect to participants' characteristics, I predict that the association between PLR and participants' share is more pronounced when participants are limited in their capacity to evaluate the credit worthiness of the borrower (empirically identified as participants that are small or growing fast). Small or growing participants are likely to be constrained in their ability to evaluate the loan information independently, as they typically have small credit risk evaluation teams and less experience in syndicated lending. Therefore, they will put greater weight on PLR in their share decisions because a lead arranger that they have a relationship with can help them to better assess loan information. Consistent with this prediction, the effect of PLR on participants' share is larger for participants with capacity limits.

Next, I examine the role of PBR and PLR in mitigating information asymmetry in loan syndicate structure and cost of debt. First, I explore the effect of PBR and PLR on loan syndicate structure. Prior literature shows that lead arrangers' share and the loan concentration index in the loan represents participants' demand for loan quality certification and monitoring (e.g., Simons 1993; Lee and Mullineaux 2004). If PBR and PLR reduce information asymmetry as predicted, then when participants with PBR or PLR take a larger share of the loan, the need for a larger lead arrangers' share and a more concentrated loan syndicate structure should be lower. Consistent with this prediction, I find that the total share taken by participants with PBR or PLR is negatively related to the lead arrangers' share and the loan concentration index. Second, I explore the effect of PBR ad PLR on cost of debt. Previous research shows that loan spread is affected by participants' demand for information asymmetry compensation (e.g., Ivashina 2009; Gadanecz et al. 2012; Amiram et al. 2016). If PBR and PLR reduce information asymmetry as predicted, I expect that the total share taken by participants with PBR or PLR is negatively related to loan spread. My analyses confirm this prediction. In particular, one standard deviation increase in the 
total share taken by participants with PBR (PLR) decreases loan spread by 1.7 (17.3) basis points. I also find that one standard deviation increase in the total share taken by participants with PLR decreases the upfront fee by 5.8 basis points.

Finally, I provide preliminary evidence on how participant-level relationship lending impacts incomplete debt contracting. ${ }^{3}$ In particular, I find that a loan package with a greater share taken by participants with PLR is more likely to be renegotiated, consistent with PLR lowering renegotiation costs (assuming that the ex-post deal amendment is a proxy for the ex-ante difficulty in obtaining support for the amendment by a majority of the lenders). Also, I examine the likelihood of interest-increase-only performance pricing and interest-decrease-only performance pricing features. As noted by Asquith et al. (2005), interest-increase-only performance pricing captures concerns with the moral hazard problem, because lenders that suffer from the moral hazard problem have the incentive to retain the right to increase interest if lead arrangers or borrowers shirk. In contrast, interest-decrease-only performance pricing captures concerns with the adverse selection problem, because lenders that suffer from the adverse selection problem and require a higher loan spread, may give the borrower a chance to reduce the loan spread ex-post. I find that a larger share taken by participants with PLR is associated with the lower likelihood of interest-increase-only performance pricing, while a larger share taken by participants with PBR is associated with the lower likelihood of interest-decrease-only performance pricing. Thus, I provide evidence that PLR helps to reduce the moral hazard problem, while PBR is more effective in mitigating the adverse selection problem.

\footnotetext{
${ }^{3}$ Incomplete debt contracting refers to the situation where lenders worry about future realizations and cannot contract ex-ante for each future state. So they use renegotiation, performance pricing and other contracting features to help them allocate control rights and better contract for uncertainties in the future (Christensen et al. 2015).
} 
My study contributes to a growing literature on syndicated loans. Prior studies have highlighted the importance of lead arranger-level relationship lending for debt contracting terms. For example, Bharath et al. (2011) shows that, in syndicated lending, borrowing from the same lead arranger lowers cost of debt, reduces collateral requirements and increases loan amount. At the same time, most of this literature assumes that participant lenders are homogeneous, uninformed lenders and they primarily depend on the lead arranger's skin in the game to ensure due diligence and monitoring. For example, Sufi (2007) finds that lead arrangers take a larger share when the borrower is opaque and thus requires more due diligence and monitoring, while Ivashina (2009) finds that a larger lead arrangers' share is associated with a lower cost of debt. In contrast, I relax this assumption and focus on a specific source of heterogeneity among participants: participants' past relationships with the borrower or the lead arranger. That is, I focus on relationship lending at the participant-level, rather than at the lead arranger-level, and examine its effects on key debt contracting outcomes.

A few studies have begun to explore some aspects of participant-level relationship lending. Sufi (2007) finds that lead arrangers are more likely to include participants with a borrower relationship when the borrower is informationally opaque, while Champagne and Kryzanowski (2007) find that participants with a lead arranger relationship are more likely to join the same lead arranger's future syndicates. Both studies, however, only examine the participants' decision to join the syndicate. I expand the investigation to the participant's loan share decision and to a series of loan-level outcomes (lead arrangers' share, loan concentration, loan spread, upfront fee, renegotiation, and performance pricing). Besides, I consider both types of relationships (i.e., PBR and PLR) simultaneously. ${ }^{4}$ Overall, my study provides the first, in-depth and comprehensive

\footnotetext{
${ }^{4}$ Another related study is Gadanecz et al. (2012), who find that participants with borrower relationships demand less compensation for information asymmetry in the form of lower loan spread. However, they do not examine the effect
} 
analysis of how participants' relationships mitigate their information asymmetry with respect to the borrower and the lead arrangers, by showing the impact of these relationships on loan syndicate structure and the terms of syndicated loans. Also, to the best of my knowledge, this is the first study to investigate the determinants of participants' share in the loan, an important question since participants as a group typically take the majority share of the loan.

The rest of the paper is organized as follows. Section 2 discusses the institutional background, the related literature and develops my hypotheses. Section 3 describes the sample selection and the empirical design. Section 4 reports the empirical results, and Section 5 concludes.

\section{Institutional Background, Related Literature and Hypothesis Development}

A syndicated loan involves two or more lenders jointly contracting with a borrower under the same credit agreement. Among the syndicate lenders, one or more lead arrangers take the lead of the credit and assume the responsibility of administering the loan for participating lenders. It is common for borrowers to hire multiple lead arrangers for their different competitive advantages in performing different duties (François and Missonier-Piera 2007). Lead arrangers benefit by getting arrangement and underwriting fees while spreading risk and credit among participants. Participants benefit by obtaining access to the loan and risk diversification without incurring origination costs and facing service burdens. The syndicated loan market is growing rapidly, largely because it combines features of sole-lender loans that sophisticated lenders can coordinate their effort to act as a group to screen, monitor and renegotiate, with the benefits of public debt contracts, namely, longer terms, larger credit amounts and looser covenants (Dennis and Mullineaux 2000; Ball et al. 2008).

\subsection{Information Asymmetry and Participant-Level Relationships in Syndicated Lending}

of borrower relationships on participants' share decision nor on the loan syndicate structure (lead arranger's share and loan concentration), and they do not examine the participant-lead arranger relationship. 
Participants' information asymmetry problems come from the syndication process in which participants delegate the loan screening and monitoring role to the lead arranger. The Federal Deposit Insurance Corporation (FDIC) describes the loan syndication process with an emphasis on participants' own credit risk assessment as follows. ${ }^{5}$ In the pre-launch phase, the lead arranger collects loan information and prepares an information memorandum based on the information provided by the borrower. In the launch phase, potential participants get the information memorandum and meet with the borrower and the lead arranger to discuss the borrower's business and negotiate pricing and other terms. In this phase, as emphasized by practitioners, participants' own information acquisition about the borrower and the lead arranger plays a key role. ${ }^{6}$

In the post launch phase, participants decide whether to join the syndication by doing their due diligence and credit approval, including running projection models with stress tests based on business and industry research. In the post-closing phase, participants discuss the borrower's financial/operating performance with the borrower and the lead arranger and follow quarterly updates on the borrower's covenant compliance. Every year, participants join meetings to obtain borrower information updates and assess the loan protection level based on annual credit analyses prepared by the lead arranger. If loan renegotiation is necessary, participants also obtain relevant proprietary borrower information to vote on loan amendments.

The delegation process impacts participants' information asymmetry with both the borrower and the lead arranger. With respect to the borrower, the participant is subject to the same

\footnotetext{
${ }^{5}$ For more detail, see Section 3-2 of FDIC's definition of syndicated loan phases available on: https://www.fdic.gov/regulations/safety/manual/section3-2.pdf

${ }^{6}$ Mugasha (1998) notes that the syndicate manager does not owe legal fiduciary duties to the participants, because participants are sophisticated parties with knowledgeable syndication departments and thus they are well equipped to carefully study loan quality and lead arranger quality before accepting the terms of the loan, and because participants engage in a direct contracting relationship with the borrower, not the lead arranger. However, lead arrangers still face legal risks if they negligently or purposely misrepresent any borrower information that causes the participants to contract with the borrower and incur losses.
} 
information problem faced by the lead arranger. That is, the participant-borrower information asymmetry problem (hereinafter PBIAP) is the same as the well-documented lead arrangerborrower information asymmetry problem (hereinafter LBIAP), which consists of (i) an adverse selection problem, arising from the possibility that the borrower does not disclose all relevant credit quality information, and (ii) a moral hazard problem, due to the fact that the borrower may act against the lenders' interests. It is important to note that because the lead arranger, due to disclosure costs or misreporting incentives, makes imperfect disclosures to participants, PBIAP is typically more severe than LBIAP.

With respect to the lead arranger, participants suffer from what I will refer to as a participantlead arranger information asymmetry problem (hereinafter PLIAP). This problem arises because the delegation process makes it necessary for participants to get information about the lead arranger's due diligence and monitoring activities and such information acquisition may not be perfect. PLIAP consists of (i) an adverse selection problem, when the lead arranger does not disclose all relevant information about loan quality, and (ii) a moral hazard problem, when the lead arranger engages in opportunistic monitoring activities. The moral hazard problem is especially relevant in syndicated lending, because lead arrangers do not take the whole share in the loan, and thus do not enjoy the full benefit of monitoring.

It is important to emphasize that even when the delegation process involves no information loss and thus there is no information asymmetry between the participant and the lead arranger (i.e., no PLIAP), the participant still faces the information asymmetry problem with the borrower (i.e., PBIAP). At the same time, even if a participant has perfect borrower information (i.e., no PBIAP), she would still face the information asymmetry problem with the lead arranger (i.e., PLIAP), because the perfect borrower information does not eliminate the lead arranger's incentives to shirk 
with respect to monitoring.

Banking theory has examined the general lender-borrower information asymmetry problem. Diamond (1984) studies a joint-monitoring setting and shows that delegated financial intermediaries face incentive problems when there is information asymmetry about their monitoring activities and when they do not receive the full benefits from monitoring - a situation similar to the case of lead arrangers in syndicated loans. Holmstrom (1979) and Holmstrom and Tirole (1997) speak directly to the lead arranger's incentive problem and its impact on participants. In their setting, the lead arranger is an informed lender that performs due diligence and monitoring, while participants are uninformed lenders that rely on the lead arranger's monitoring and information. However, the lead arranger's action is unobservable, which gives the lead arranger incentive to take opportunistic actions that are not in the best interest of participants. To solve this incentive problem, participants require the lead arranger to take a large enough share in the loan.

Unlike the settings in Holmstrom (1979) and Holmstrom and Tirole (1997), I relax the assumption that participants are uninformed and predict that participants with a borrower relationship will obtain proprietary information about the borrower that helps mitigate the PBIAP in a subsequent deal, while participants with a lead arranger relationship will obtain information about the lead arranger's due diligence and monitoring that helps mitigate the PLIAP in a subsequent deal. Therefore, participants with a borrower or a lead arranger relationship (i.e., with PBR or PLR) will be inclined to take a larger share in the loan. Thus, I state my first research hypothesis as follows:

H1 - Participants with a borrower or a lead arranger relationship take a larger share in the loan. 
In essence, while prior literature has focused on the lead arranger's share as a key mechanism used by participants to protect themselves from information asymmetry problems, I propose that past relationships with the borrower and the lead arrangers also mitigate this problem.

A few prior studies have identified the importance of these relationships for the participants' decision to join the syndicate. For example, Sufi (2007) finds that lead arrangers are more likely to include participants with a borrower relationship when the borrower is informationally opaque, while Champagne and Kryzanowski (2007) find that participants with a lead arranger relationship are more likely to be invited to the same lead arranger's future syndicates. However, these findings do not imply a similar result for the participants' decision concerning the share of the loan. First, participants with a borrower or a lead arranger relationship might want to take a smaller share to diversify risk (across borrowers and across lead arrangers), especially when they have outstanding loans with the same borrower or the same lead arranger because of the relationship. Thus, past relationships with the borrower or the lead arranger may have no association or a negative association with participants' share in the loan. Second, no matter what the prior information endowment of the participant is, lead arrangers and borrowers can help level the playing field for all participants, as lead arrangers may potentially benefit from taking a smaller share and borrowers may benefit from a lower cost of debt. Therefore, the previous information endowment brought by relationship lending can be irrelevant. ${ }^{7}$ Hence, the prediction in $\mathrm{Hl}$ is not without tension.

\subsubsection{Cross-Sectional Predictions: Borrower Characteristics}

\subsubsection{Borrower Information Opacity}

\footnotetext{
${ }^{7}$ In addition, even if the participants without any relationships are informationally inferior, they can observe how much participants with relationships take, and use such share-taking observations as a signal of how much they can take. In other words, participants without PBR and PLR can take as much share as participants with PBR and PLR because the two kinds of participants face the same major benefit (loan spread) and cost (default risk). In this case, relationship lending can also be potentially irrelevant.
} 
An opaque borrower has a larger PBIAP, with a more severe adverse selection problem with respect to loan quality and a more severe moral hazard problem from the borrower's opportunistic actions against participants' interests. Indeed, using different proxies for opacity, a number of studies find that relationship lending is more beneficial for opaque borrowers. For example, Petersen and Rajan (1994) find that for small and thus potentially more opaque firms, borrowing from a previous lender results in greater access to capital and a lower cost of debt. Similarly, Berger and Udell (1995) argue that smaller firms suffer more from asymmetric information problems, and borrowers with a longer banking relationship pay lower interest rates and are less likely to be required to pledge collateral. More recently, Sufi (2007) predicts that borrowers that have no credit rating or are not listed suffer more from information asymmetry problems and finds that, for those borrowers, participants require lead arrangers to take a larger share in the loan. Bharath et al. (2007) show that loans originated by repeat lead arrangers have lower cost of debt, with the effect being more pronounced when the borrower is less transparent. Khan et al. (2016) find that a lender's relationship with a manager is not only specific to the firm where the relationship developed, but also migrate to other firms that the manager joins, especially if the new firm is informationally opaque.

Along the same lines, I predict that PBR is more important when lending to opaque borrowers because past transactions with the borrower endow participants with an information advantage and decrease PBIAP, thus allowing them to take a larger share in the loan. I do not make predictions for PLR because it is not clear whether a past relationship between the participant and the lead arranger helps mitigate the severe PBIAP for more opaque borrowers. My research hypothesis 2.1 is thus stated as follows:

H2.1 - The effect of PBR on participants' share is larger for opaque borrowers. 


\subsubsection{Borrowers' Accounting Conservatism}

Borrowers' accounting conservatism helps lenders to observe early signals about the borrowers' default risk (Zhang 2008). These signals are less important for lenders that have a borrower relationship because these lenders have customer-specific information that facilitates monitoring (e.g., Boot 2000; Bharath et al. 2011). Consistently, Erkens et al. (2014) find that lenders with a borrower relationship have lower demand for conservative accounting. Along the same lines, I predict that PBR is more important when lending to less conservative borrowers because past transactions with the borrower endow participants with an information advantage and decrease participants' demand for conservatism, thus allowing them to take a larger share in the loan. I do not make predictions for PLR because it is not clear whether a past relationship between the participant and the lead arranger lowers the participant's demand for accounting conservatism. My research hypothesis 2.2 is thus stated as follows:

H2.2 - The effect of PBR on participants' share is larger for less conservative borrowers.

\subsubsection{Borrowers' Past Accounting Irregularities}

Past accounting irregularities have an adverse impact on lenders' views of the borrower's default risk, resulting in stricter lending terms. After a material restatement, lenders offer substantially less favorable loan terms to borrowers (Graham et al. 2008). As for firms with allegedly misstated financial statements, the enforcement actions by the U.S. Securities and Exchange Commission (SEC) (i.e., the SEC's Accounting and Auditing Enforcement Releases) result in forced management turnovers, negative abnormal returns, higher bid-ask spreads and lower analyst following (Feroz et al. 1991; Dechow et al. 1996).

I predict that participants value a lead arranger relationship more (and, thus, take a larger share in the loan) when borrowers have engaged in accounting irregularities because they can rely on the lead arranger's ability to monitor such borrowers. In contrast, I do not make a similar 
prediction for participants with a borrower relationship, since private information about the borrower does not mitigate the adverse impact of borrower accounting irregularities. As a result, my research hypothesis 2.3 is stated as follows:

H2.3 - The effect of PLR on participants' share is larger for borrowers with accounting irregularities.

\subsubsection{Borrowers' Previous Loan Performance}

Covenant violations indicate the borrower's failure to comply with loan contracting agreements and thus directly affect the lender's trust in the borrower. As a consequence, borrowers suffer from an increase in interest rates, a decline in investments, and an increase in management turnover (e.g., Roberts and Sufi 2009; Nini et al. 2012).

I predict that participants value a lead arranger relationship more (and, thus, take a larger share in the loan) when borrowers have performed poorly in past loans (i.e., they violated covenants) because they can rely on the lead arranger's ability to monitor such borrowers and avoid future covenant violations. In contrast, I do not make a similar prediction for participants with a borrower relationship, since private information about the borrower does not necessarily mitigate the risk of future covenant violations. My research hypothesis 2.4 is thus stated as follows:

H2.4 - The effect of PLR on participants' share is larger for borrowers who have performed poorly in past loans.

\subsubsection{Cross-Sectional Predictions: Lead Arranger Characteristics}

Lead arranger characteristics may help reduce the PLIAP and thus affect the relation between PLR and participants' share. I focus on two kinds of lead arrangers: repeat lead arrangers (i.e., lead arrangers who already have a relationship with the borrower) and large lead arrangers (i.e., lead arrangers with a large market share in the syndicated loan market). 
Repeat lead arrangers have lower borrower-specific information gathering costs and incur smaller monitoring costs (due to their ongoing relationships with the borrower). Besides, they want to protect their reputation with the borrower to maintain the relationship. As a result, I predict that participants can rely more on PLR to solve the moral hazard problem when there is a repeat lead arranger. As for large lead arrangers, because of their resources and experience in the syndicated lending, they generally incur lower information gathering costs and smaller monitoring costs. Also, they have strong incentives to protect their reputation in the market. Thus, I predict that participants rely more on PLR to solve the moral hazard problem when there is a large lead arranger. These arguments echo similar arguments in the literature. For example, Dennis and Mullineaux (2000) show that lead arranger reputation increases the likelihood of loan syndication. Sufi (2007) finds that repeat lead arrangers help mitigate, but do not fully eliminate, the information asymmetry problem in debt contracting. Bushman and Wittenberg-Moerman (2012) document that borrowers with loans originated by large lead arrangers realize better future performances. Chaudhry and Kleimeier (2015) show that lead arrangers' market share and their information advantage from repeat lending to the same borrower decrease lead arrangers' share of the loan and loan concentration index.

As for PBR, I do not make a directional prediction, since it is not clear whether the value of the participant's relationship with the borrower is affected by the lead arranger characteristics. Accordingly, my third research hypothesis is stated as follows:

$H 3$ - The effect of PLR on participants' share is larger for repeat lead arrangers and large lead arrangers.

\subsubsection{Cross-Sectional Predictions: Participant Characteristics}


I conjecture that participants that are small or growing fast have limited capacity to evaluate the loan information independently, as they have less experience in syndicated lending. Also, small participants include many regional and community banks with limited credit risk assessment capacities. Similarly, fast growing participants are typically smaller, and their credit risk assessment capacity may need time to catch up with their growth. Therefore, PLR can help participants with information acquisition capacity issues to better evaluate loan quality, leading me to predict that the effect of PLR on participants' share is higher for participants with limited information acquisition capacity. ${ }^{8}$

In contrast, the prediction on PBR is not ex-ante clear, because small or fast growing participants may not be able to fully exploit their past relationships with borrowers due to their limited capacity. Accordingly, I state my fourth research hypothesis as follows:

H4 - The effect of PLR on participants' share is larger for participants with information acquisition capacity limits.

\subsection{Participant-Level Relationships and Loan Syndicate Structure}

Prior literature on loan syndicate structure consistently finds that lead arrangers retain a larger share in loans that need more due diligence and monitoring. For example, prior literature shows that the lead arranger's share is larger when borrowers have lower examiner ratings (Simons 1993) or when the lead arrangers is less reputable (Dennis and Mullineaux 2000). Along the same lines, Lee and Mullineaux (2004) show that syndicates are more concentrated when the borrower is more opaque and thus entails higher credit risk. Finally, Sufi (2007) shows that the lead arranger

\footnotetext{
${ }^{8}$ A second rationale for my prediction on PLR is that small participants with a lead arranger relationship may be more willing to take a larger share in the loan if they believe that doing so will lead them to be invited by the same lead arranger in future syndicate deals. Along these lines, Champagne and Kryzanowski (2007) find that participants with a lead arranger relationship are more likely to be invited to the same lead arranger's future syndicate deals. They, however, do not examine whether this likelihood increases with the participant's share in the loan.
} 
retains a larger share and forms a more concentrated syndicate to mitigate the moral hazard problem when the borrower requires more intense monitoring and due diligence.

Overall, these studies suggest that a greater lead arrangers' share and greater loan concentration are used to mitigate concerns with loan quality and moral hazard. In a similar vein, I predict that the presence of participants with a past relationship with the borrower and lead arrangers may mitigate these concerns, and thus it will be associated with lower lead arrangers' share and lower loan concentration, leading to the following hypothesis:

H5 - The higher the share of the loan taken by participants with a borrower relationship or a lead arranger relationship, the lower the lead arranger's share in the loan and the lower the loan concentration.

\subsection{Participant-Level Relationships and Cost of Debt}

Previous studies find that a lead arranger's past relationship with the borrower is associated with a lower cost of debt (Bharath et al. 2011), consistent with the notion that relationship lending reduces the demand for an information asymmetry risk premium. In contrast, Rajan (1992) argues that relationship lending may result in hold-up problems with incumbent relationship banks exploiting their information rents and charging higher interest rates. Consistent with this theory's prediction, Degryse and Van Cayseele (2000), when investigating European small businesses, find that longer bank-firm relationships are associated with higher interest rates. However, the argument in Rajan (1992) seems to apply to the lead arranger's relationship, since only the lead arranger can exploit the hold-up problem. In the case of participants, I predict that relationship lending will result in a lower loan spread.

Note that prior literature usually defines cost of debt as the loan spread (i.e., the amount a borrower pays in basis points over LIBOR for each dollar drawn down including any annual fees), 
but it overlooks any upfront fees that the borrower pays to the lenders at loan initiation. The upfront fee is often tiered, with the lead arranger receiving the major amount for the loan origination. According to Gadanecz (2004), the upfront fee paid to the lead arranger includes an arrangement fee that compensates for the cost of lead arrangers putting the deal together, and an underwriting fee that compensates for the risk of lead arrangers guaranteeing the availability of the fund. This guarantee means that in case of attracting insufficient participants, lead arrangers need to absorb the unallocated amount. Consistent with the view that the upfront fee compensates for syndication cost and syndication risk, Berg et al. (2015) find that the upfront fee increases with borrowers' equity and profit volatility.

Overall, the upfront fee is part of the total borrowing cost that is not captured by loan spread and has different functions as an additional cost of debt: while the loan spread mainly compensates for information asymmetry risk and default risk during the loan outstanding period, the upfront fee mainly compensates for loan syndication cost and syndication risk at loan initiation. Given that the loan spread and the upfront fee capture different aspects of cost of debt, I examine both of them in Hypothesis 6. I predict that the loan spread will be lower for participants with a borrower relationship or a lead arranger relationship because these participants demand lower compensation for information asymmetry risk. I predict that the upfront fee will also be lower for participants with a borrower relationship or a lead arranger relationship because these relationships can decrease the cost of lead arrangers putting the deal together (i.e., syndication cost decreases), as well as decrease the risk of lead arranger absorbing the remaining amount of unsuccessful participation (i.e., syndication risk decreases). Therefore, $H 6$ is stated as follows:

H6 - The higher the share of the loan taken by participants with a borrower relationship or a lead arranger relationship, the lower the cost of debt for the borrower. 
Preliminary support for this hypothesis regarding loan spread and borrower relationship is already in Gadanecz et al. (2012), who find that participants with a borrower relationship demand a lower loan spread. However, they do not investigate the cases of participants with a lead arranger relationship and the additional cost of debt measured by the upfront fee.

\section{Sample Selection and Empirical Design}

\subsection{Sample Selection}

To determine the role of participant relationships in syndicated lending, I start with syndicated loan package data available in Loan Pricing Corporation's DealScan database from 1990 to 2012. I merge loan package data with Compustat through the linking table provided by Chava and Roberts (2008) to identify nonfinancial U.S. firms with financial information available. ${ }^{9}$ For these loans, I obtain lender information from DealScan. Similar to Bharath et al. (2011) and Sufi (2007), I define lenders as lead arrangers when the variable "Lead Arranger Credit" is defined as "Yes". ${ }^{10}$ The rest of the lenders in a loan package are defined as participants. To focus on syndicated loans with both lead arrangers and participants, I delete loans when no lead arranger is identified, and when there is no participant identified in sole-lender loans. To identify participantborrower relationships, I require each loan package in my sample to have at least one prior loan package for the same borrower in the previous 5 years. Next, I restrict my sample to loans that have data on loan share allocation and loan spread, my two primary dependent variables. Finally, I require firm-level control variables (specifically, a borrower's total assets, net income before

\footnotetext{
${ }^{9}$ My sample ends at 2012 because it's the last year covered in the linking table provided by Chava and Roberts (2008) in Dealscan.

${ }^{10}$ For $8 \%$ of loan packages there is no lender with the variable "Lead Arranger Credit" defined as "Yes". For these loan packages, I define a lender as lead arranger if it performs any of the five roles most frequently associated with lenders for whom "Lead Arranger Credit" is defined as "Yes", namely, Administrative Agent (46\%), Agent (27\%), Arranger (10\%), Syndications Agent (8\%) and Book Runner (2\%). For robustness, I exclude these loan packages and obtain similar results.
} 
extraordinary items, long-term debt and net property, plant and equipment) to be available. My final sample comprises 5,989 loan packages, which is comparable to prior literature. ${ }^{11}$ Table 1 , Panel A summarizes the sample selection process. All variables described in this section are detailed in Appendix A.

\subsection{Empirical Design}

To test my hypotheses on how participants' relationships affect participant share $(H 1-H 4), I$ first employ the following OLS regression at the participant level with package and year fixed effects:

Participant Share $=\beta_{1}+\beta_{2} P B R+\beta_{3} P L R+\beta_{4}$ Industry Exposure $+\beta_{5}$ Lender Type + Package Fixed Effects + Year Fixed Effects $+\varepsilon$.

My dependent variable is Participant Share, which is defined as the amount of the loan taken by a participant divided by the total amount of the loan. ${ }^{12}$ My participant-level variables of interest are $P B R$ (participant-borrower relationship) and $P L R$ (participant-lead arranger relationship). $P B R$ is an indicator variable equal to 1 if the participant has lent to the borrower within the past 5 years, and 0 otherwise. $P L R$ is an indicator variable equal to 1 if the participant has joined a lead arranger's syndicate in any other firm within the past 5 years, and 0 otherwise. Similar to prior studies (e.g., Bharath et al. 2011), I choose 5 years to measure PBR and PLR because 5 years are a long enough period to capture prior loans (the average maturity of a

\footnotetext{
${ }^{11}$ For example, Sufi (2007) has 4,414 loans with available share allocation information over the 1992-2003 period. His sample includes both listed and non-listed borrowers.

${ }^{12}$ I focus on participants' share taken at loan initiation. This may raise a concern with whether loan share will change as a result of loan sales in the secondary market. The market of loan sales is smaller than the syndicated loan market and mostly for financial distressed borrowers (Dahiya et al. 2003; Wittenberg-Moerman 2008). This is partly due to the complexity of transferring the illiquid loan-asset with non-standardized loan agreements. Also, if lenders want to transfer their shares, in most cases they need to get the written consent of the borrower. Borrowers typically object to such transfers because of potential added risk of the increased lender pool. Nonetheless, in untabulated robustness tests, I exclude institutional loans (737 of the 5,989 loan in my sample), for which loan sales are more frequent, and my inferences are unchanged.
} 
syndicated loan is about 3.9 years), but not so long to make the information acquired through the past relationship irrelevant. In robustness tests, I will examine the sensitivity of the results to alternative definitions.

My participant-level control variables are Industry Exposure and Lender Type. Industry Exposure is defined as an indicator variable equal to 1 if the loan is to a borrower in one of the top 5 industries that the participant has lent to within the prior 3 years, and 0 otherwise. Industry Exposure may be a proxy for sector-based diversification needs. I expect a participant with high exposure to a given industry to prefer to take a smaller loan share when lending to borrowers in that industry. ${ }^{13}$ On the other hand, it is possible that participants prefer to lend to sectors they have specific expertise in and past experience with, leading to predict a positive association. Lender Type is an indicator variable equal to 1 if the participant is a depository institution, and 0 otherwise. A depository institution is the typical commercial bank in syndicated lending, while other lenders include investment banks and institutional investors. I conjecture that depository institutions, traditionally more familiar with the syndicated loan market, may be willing to take a larger share.

In Equation (1), all the variations come from differences in the participant-level characteristics within the same package. Next, I modify Equation (1) to include borrower-level and package-level controls and estimate the following OLS regression at the participant level with borrower fixed effects (rather than package fixed effects) and year fixed effects:

$$
\begin{aligned}
& \text { Participant Share }=\beta_{1}+\beta_{2} P B R+\beta_{3} P L R+\beta_{4} \text { Industry Exposure }+\beta_{5} \text { Lender Type }+ \\
& \beta_{6} \text { Borrower Size }+\beta_{7} \text { Profitability }+\beta_{8} \text { Leverage }+\beta_{9} \text { Tangibility }+ \\
& \beta_{10} \text { Credit Rating Availability }+\beta_{11} \text { Lead Arranger Share }+ \\
& \beta_{12} \text { Repeated Lead Arranger }+\beta_{13} \text { Large Lead Arranger }+
\end{aligned}
$$

\footnotetext{
${ }^{13}$ Industry exposure is an imperfect proxy in that it is based on shares held in past loans at initiation. It does not take into account any loan sales or CDS trading that may impact the actual risk on the participant's book.
} 


$$
\begin{aligned}
& \beta_{14} \text { Number of Lead Arrangers }+\beta_{15} \text { Number of Participants }+ \\
& \text { Borrower Fixed Effects }+ \text { Year Fixed Effects }+\varepsilon .
\end{aligned}
$$

In addition to the four participant-level variables defined in Equation 1, I control for borrower-level and package-level variables. As for the former, I include a series of variables examined in other studies on loan syndicate structure (e.g., Lee and Mullineaux 2004; Sufi 2007): Borrower Size, defined as the natural logarithm of a borrower's total assets; Profitability, defined as the ratio of a borrower's net income before extraordinary items to total assets; Leverage, defined as the ratio of a borrower's long-term debt to total assets; Tangibility, defined as the ratio of a borrower's net PPE to total assets; and Credit Rating Availability, defined as an indicator variable equal to 1 if the $\mathrm{S} \& \mathrm{P}$ domestic long-term issuer credit rating is available for a borrower and 0 otherwise. All these variables are measured at the end of the most recent fiscal year before loan origination, except Credit Rating Availability, which is measured at the end of the most recent fiscal month before loan origination (source: Compustat). I expect that when a borrower has larger size, higher profitability, lower leverage, higher tangibility and credit rating available, participants are more willing to take a larger share in the loan. ${ }^{14}$ However, these are cross-sectional predictions, capturing how participants' decisions will differ across different borrowers. In my specification, with borrower fixed effects, the interpretation of these variables is somewhat different, since I am effectively examining how participants' decisions will differ across packages within the same borrower. I will return to this point when discussing my empirical results.

As for the package-level controls, Lead Arranger Share is defined as the amount of loan taken by the lead arranger divided by the total amount of the loan. If there is more than one lead

\footnotetext{
${ }^{14}$ The rationale for these predictions is that larger firms and firms with credit ratings are less informationally opaque, more profitable firms and firms with low leverage have greater repayment ability and firms with more tangible assets offer greater collateral. Thus, participants are willing to take a larger share of the loan in these firms.
} 
arranger, it is calculated as the average percentage of shares of all lead arrangers (following Sufi 2007). ${ }^{15}$ Repeat Lead Arranger is defined as an indicator variable equal to 1 if the lead arranger has lent to the borrower within the past 5 years, and 0 otherwise, as in Bharath et al. (2011). Large Lead Arranger is defined as an indicator variable equal to 1 if the lead arranger is among the top 5 lead arrangers in terms of syndicated loan market share in the prior year, and 0 otherwise. Number of Lead Arrangers is defined as the number of lead arrangers in a loan package. Number of Participants is defined as the number of participants in a loan package. I do not control for loan package size because it is highly correlated with borrower size (correlation: 0.61; untabulated).

To test my hypothesis on the effect of participant-borrower relationship and participant-lead arranger relationship on loan syndicate structure (H5), I employ the following OLS regression at the loan package level with industry and year fixed effects:

Loan Syndicate Structure

$$
\begin{aligned}
& =\beta_{1}+\beta_{2} \text { Total PBR Share }+\beta_{3} \text { Total PLR Share }+\beta_{4} \text { Borrower Size } \\
& +\beta_{5} \text { Profitability }+\beta_{6} \text { Leverage }+\beta_{7} \text { Tangibility } \\
& +\beta_{8} \text { Credit Rating Availability }+\beta_{9} \text { Repeated Lead Arranger } \\
& +\beta_{10} \text { Large Lead Arranger }+\beta_{11} \text { Number of Lead Arrangers } \\
& +\beta_{12} \text { Number of Participants }+ \text { Industry Fixed Effects } \\
& + \text { Year Fixed Effects }+\varepsilon .
\end{aligned}
$$

Loan Syndicate Structure is alternatively measured as Lead Arranger Share (defined as above) or Herfindahl Index, a commonly used loan concentration index calculated as the sum of

\footnotetext{
${ }^{15}$ In unreported tests I repeat my analyses for the subset of loans with a single lead arranger and obtain similar results.
} 
squared shares of all lenders in a loan package, theoretically ranging from 0 to $10,000 .{ }^{16}$ The loan syndicate structure test is at the package level since the syndicated loan contract is drafted at the package level. ${ }^{17}$ As a result, the participant-level variables of interest (PBR and PLR in Equation (2)) are now re-defined at the loan package level. In particular, Total PBR Share is defined as the amount of loan taken by all the participants with a borrower relationship in the loan, divided by the total amount of the loan. Total PLR Share is defined as the amount of loan taken by all the participants with a lead arranger relationship in the loan, divided by the total amount of the loan. The other control variables are defined as above..$^{18}$

Finally, to test my hypothesis on the effect of participant-borrower relationship and participant-lead arranger relationship on the cost of debt (H6), I employ the following OLS regression at the loan facility level with industry and year fixed effects:

$$
\begin{aligned}
& \text { Cost of Debt }=\beta_{1}+\beta_{2} \text { Total PBR Share }+\beta_{3} \text { Total PLR Share }+\beta_{4} \text { Borrower Size }+ \\
& \beta_{5} \text { Profitability }+\beta_{6} \text { Leverage }+\beta_{7} \text { Tangibility }+ \\
& \beta_{8} \text { Credit Rating Availability }+\beta_{9} \text { Repeated Lead Arranger }+ \\
& \beta_{10} \text { Large Lead Arranger }+\beta_{11} \text { Number of Lead Arrangers }+ \\
& \beta_{12} \text { Number of Participants }+\beta_{13} \text { Loan Maturity }+\beta_{14} \text { Secured Loan }+ \\
& \beta_{15} \text { Loan Facility Size }+ \text { Industry Fixed Effects }+ \text { Year Fixed Effects }+\varepsilon .
\end{aligned}
$$

\footnotetext{
${ }^{16}$ The higher the Herfindahl Index, the higher the concentration of the loan. For example, in the extreme cases of loans with only one lender, Herfindahl Index takes the value of 10,000 $(=100 * 100)$.

${ }^{17}$ Similar to Sufi (2007), I perform the test at the package level rather than at the facility level. Since lenders' share allocation is the same across different facilities within the same loan package, facility-level observations would not be independent, causing standard errors to be understated and boosting significance levels. As a result, I do not include control variables that vary across facilities within the same loan, such as loan spread and other loan terms.

${ }^{18}$ Compared to Equation (3), Equation (4) does not control for Lead Arranger Share (since it is a measure of loan syndicate structure, and thus one of the dependent variables) and for the participant-level variables, since the analysis is at the package-level.
} 
This analysis is performed at the facility level because there can be multiple loan facilities in a loan package depending on the facility type (e.g., term loan facility and revolver loan facility) and the facility purpose (e.g., working capital purpose and debt repayment purpose), and thus each facility has its own loan terms, such as spread, maturity, security and so on. Cost of debt is measured by Loan Spread and Upfront Fee. The first dependent variable, Loan Spread, is defined as the amount a borrower pays in basis points over LIBOR for each dollar drawn down including any annual fees. The second dependent variable, Upfront Fee, is defined as the one-time fee paid by the borrower to lenders at loan initiation. Following prior literature, in addition to the other variables in Equation (3), I include a series of facility-level control variables that potentially affect cost of debt (e.g., Ivashina 2009). In particular, Loan Maturity is defined as the number of months a facility will be active from signing date to expiration date. Secured Loan is defined as an indicator variable equal to 1 if a facility is secured and 0 otherwise. Facility Size is defined as the actual amount of the facility in millions committed by the facility's lender pool.

\section{Empirical Analyses}

\subsection{Summary Statistics}

In Table 1 Panel B, I report summary statistics of my key variables. To address concerns with outliers, I winsorize the variables at $1 \%$ and $99 \%$ levels. There are 61,373 participants $(3,010$ unique participants) in 5,989 loan packages. The primary dependent variable is Participant Share. On average, a participant takes $6.8 \%$ of the loan package, which is about $1 / 3$ of the average lead arranger's share (21.1\%). As for the participant-level variables of interest, $P B R$ has a mean value of 0.41 , while PLR has a mean value of 0.84 . That is, on average, $41 \%$ of all participants have lent to the borrower before, while $84 \%$ of all participants have joined a lead arranger's syndicate before. 
The participant-level control variables indicate that $35 \%$ of the loans are made to borrowers within the top 5 industries that the participant has lent to in the past 3 years (Industry Exposure). $80 \%$ of the participants are commercial banks (Lender Type $=1$ ). For the borrower-level control variables, there are 2,314 borrowers for 5,989 packages. On average borrowers have total assets of $\$ 4,559.34$ million, a profitability ratio of 0.03 , a leverage ratio of 0.26 and a tangibility ratio of 0.37. $47 \%$ of the borrowers have recent $\mathrm{S} \& \mathrm{P}$ domestic long-term issuer credit rating available (Credit Rating Availability).

For the package-level variables, the mean Lead Arranger Share is $21.1 \%$ of the loan. $37 \%$ of the packages have at least one Repeat Lead Arranger, while $45 \%$ of the packages have at least one Large Lead Arranger. The average Number of Lead Arrangers and Number of Participants, are, respectively, 1.58 , and 10.25 per loan package. Participants with a borrower relationship on average take $28 \%$ of the loan as a group (Total PBR Share), while participants with a lead arranger relationship on average take $57 \%$ of the loan as a group (Total PLR Share). As for the facilitylevel variables, a loan facility on average has a loan spread of 146 basis points, an upfront fee of 43 basis points, matures in 45 months, is secured $42 \%$ of the times, and amounts to $\$ 501$ million. There are 7,688 facilities for 5,989 packages, in which 1,964 facilities have available the upfront fee information.

In Table 1 Panel C, I list names of the top 5 participants in terms of PBR and PLR intensity. Bank of New York is the most PBR-intensive participant lender, averaging 1.41 transactions with the borrower within the prior 5 years for each loan Bank of New York participated in, with the other top 4 participants ranging between 1.25 and 1.38 transactions. US Bank is the most PLRintensive participant lender, averaging 191 transactions with the lead arranger within the prior 5 years, with the other top 4 participants ranging from 103 to 145 transactions. Notably, the top 5 
participants engaging in relationship lending (PBR or PLR) do not overlap much with the top lead arranger lenders. The top 5 lead arrangers in terms of 2012 US market share are: JP Morgan (18.28\%), Bank of America Merrill Lynch (16.07\%), Citi (9.86\%), Wells Fargo (9.45\%) and Barclays (5.51\%) (Source: Bloomberg). Lead arrangers tend to be larger than participant lenders, with lead arrangers having an average asset size about eight times larger than participant lenders (Altunbaş and Kara (2011).

\subsection{The Effect of PBR and PLR on Participants' Share in the Loan}

Table 2 analyzes the effect of PBR and PLR on a participant's share in the loan. In a specification using package fixed effects (Column 1), I find that a participant with a borrower relationship (PBR) on average takes a $0.74 \%$ larger share, while a participant with a lead arranger relationship (PLR) on average takes a $0.95 \%$ larger share. These figures represent, respectively, an $11 \%$ and a $14 \%$ increase relative to the mean participant share of $6.83 \%$. The results are consistent with my prediction in $H 1$. As for the participant-level control variables, the positive coefficient on Lender Type indicates that being a traditional commercial bank increases the share taken by participants. The coefficient on Industry Exposure is positive but not significant, perhaps as a result of the offsetting pressure to lend to familiar sectors and diversify risks.

Next, I re-estimate the same OLS regression including borrower fixed effects to allow for the inclusion of borrower-level and package-level control variables and thus also prepare for the subsequent cross-sectional analyses. As shown in Column 2, the results are generally similar. A participant with PBR (PLR) on average takes a $0.67 \%(0.63 \%)$ larger share, a 10\% (9\%) increase relative to the mean participant share of $6.83 \%$. The coefficient of Lender Type remains positive and significant. 
As for the borrower-level control variables, some of the coefficients may seem at odds with intuition. For example, we would expect a positive, rather than negative coefficient of Borrower Size (a proxy for information opacity). However, as mentioned in Section 3, because of the inclusion of borrower fixed effects, these coefficients need to be interpreted with caution, since participants within the same package face the same borrower characteristics. ${ }^{19}$ To ensure that borrower-level control variables behave as expected, I replicate in my sample prior literature's result that participants as a group hold more when borrowers are less informationally opaque and when lead arrangers are relationship lenders with the borrower (e.g., Sufi 2007). To do so, I use participants' total share as my dependent variable and confirm that it is positively related to borrower size/profitability/credit rating availability (see Appendix B).

\subsubsection{Robustness Tests}

To ensure the robustness of my primary result in Table 2 (the positive association between PBR/PLR and participant share), I perform several robustness checks (see Appendix C-E). First, I make sure that my result is not sensitive to the use of a 5-year window to define relationship loans, i.e., the PBR and PLR variables. The results are similar when (i) PBR is defined as equal to 1 if the participant has lent to the borrower in the past and the loan is still outstanding, and 0 otherwise; and (ii) $P L R$ is equal to 1 if the participant has joined a lead arranger's syndicate loan with any borrower in the past and that loan is still outstanding, and 0 otherwise. Second, I make sure that my results are not driven by cases where a participant has both lead arranger relationship and borrower relationship in the same loan. I re-run the test in Table 2, Column 2, adding an interaction term for PBR*PLR and confirm that the main effect on PBR and PLR remain significant and of

\footnotetext{
${ }^{19}$ In other words, the coefficients cannot be interpreted as evidence of how cross-sectional differences in firm characteristics among borrowers affect participants' individual share decisions. Instead, the coefficients reflect the effect of changing firm characteristics from one package to the other within the same firm, among firms with multiple packages.
} 
similar magnitude (respectively, equal to 0.71 and 0.64 , both significant at $1 \%$ level), while the interaction coefficient is insignificant. Third, I replace PBR and PLR with corresponding variables capturing the intensity of the relationship, with PBR Intensity equal to the number of the participant's transactions with the borrower within the prior 5 years, and PLR Intensity equal to the number of the participant's transactions with the lead arranger (in any borrower) within the prior 5 years. For participants with a borrower relationship, the mean PBR Intensity is 1.85 (with an interquartile range from 1 to 2 and a maximum of 10) and mean PLR Intensity is 60 (interquartile range between 6 and 72). Both the coefficient of PBR Intensity and PLR Intensity are positive and significant (respectively, equal to 0.28 and 0.003 , both significant at $1 \%$ level), suggesting that the intensity of the relationship, not just its presence, matters.

Next, I re-run the test in Table 2 for the subset of 4,637 loans (out of the total sample of $5,989)$ with a single facility, so as to be able to introduce a series of facility-level variables: loan spread, loan maturity, secured loan, facility size (see Table 1 , Panel B) ${ }^{20}$ I continue to find positive and significant coefficients on PBR and PLR (respectively, equal to 0.60 and 0.69 , both significant at $1 \%$ level, Appendix F).

Finally, my interpretation of Table 2 is based on the assumption that the participation choice of participants with PBR or PLR is exogenous, after controlling for borrower characteristics, participant characteristics, lead arranger characteristics, loan characteristics, borrower fixed effects and year fixed effects. However, this assumption may not be valid if some unobserved omitted variables affect both the incidence of PBR and PLR, as well as participants' share. First, to rule out the alternative explanation that participants prefer to continue their relationship only with borrowers who have better prior loan performances, and that they also take a larger share in those

\footnotetext{
${ }^{20}$ See footnote 17 for a discussion of the problem of running the tests at the facility-level.
} 
borrowers' subsequent loans, I split the sample based on prior loan performance (measured by covenant violations). I find that for loan deals with covenant violations within 5 years of loan initiation, the ratio of participants with PBR or PLR is not significantly lower than loan deals without covenant violations. ${ }^{21}$ Second, to further address the endogeneity problem, I adopt the Propensity Score Methodology (PSM) as in Rosenbaum and Rubin (1983). My first PSM robustness test is for PBR. Specifically, for each test loan deal that a lender takes and has a borrower relationship (i.e., a loan deal with PBR=1), I identify a matched loan deal that the same lender takes and has no borrower relationship (i.e., a loan deal with $\mathrm{PBR}=0$ ), but is in every other way similar to the test loan deal (i.e., has the closest propensity score). My second PSM robustness test is for PLR. Similarly, for each test loan deal that a lender takes and has a lead arranger relationship (i.e., a loan deal with PLR=1), I identify a matched loan deal that the same lender takes and has no lead arranger relationship (i.e., a loan deal with PLR=0) but is in every other way similar to the test loan deal. ${ }^{22}$ In Appendix G for the PSM robustness test, I confirm the effect of PBR on participants' share-taking decisions after PSM is similar in terms of magnitude and significance level as in Table 2 (after PSM, the coefficient on PBR is equal to 0.723 , significant at $1 \%$ ). I am also able to confirm the effect of PLR (after PSM, the coefficient on PLR is equal to 0.501 , significant at $1 \%$ ).

\subsubsection{Cross-sectional Determinants: Borrower Characteristics}

In Table 3, I begin to explore how the effect of PBR and PLR on participants' share in the loan (the key result in Table 2) varies with a number of cross-sectional determinants, starting with

\footnotetext{
${ }^{21}$ Specifically, the ratio of participants with PBR in loan deals with (without) prior covenant violations $=0.415$ (0.414), with a t-stat for the difference=-0.19. In the case of PLR, the ratio of participants with PLR in loan deals with (without) prior covenant violations $=0.801(0.847)$, with a t-stat for the difference $=6.56$. Although the difference is statistically significant, it's not economically significant.

${ }^{22}$ The propensity score is calculated based on the coefficient estimates from the following logit models: $P B R$ (in test $2, P L R)=\beta_{1}+\beta_{2} P L R$ (in test $\left.2, P B R\right)+\beta_{3}$ Industry Exposure $+\beta_{4}$ Lender Type + $\beta_{5}$ Borrower Size $+\beta_{6}$ Profitability $+\beta_{7}$ Leverage $+\beta_{8}$ Tangibility $+\beta_{9}$ Credit Rating Availability + $\beta_{10}$ Lead Arranger Share $+\beta_{11}$ Repeated Lead Arranger $+\beta_{12}$ Large Lead Arranger + $\beta_{13}$ Number of Lead Arrangers $+\beta_{14}$ Number of Participants $+\varepsilon$.
} 
borrowers' characteristics. First, in Panel A, I examine borrowers' information opacity. As noted in H2.1, I predict that the effect of PBR on participants' share is stronger for opaque borrowers, because for these borrowers, PBR is more useful in mitigating information asymmetry, allowing the participants to take a larger share. I separately examine three proxies for (higher) borrower information opacity: Small Borrower, No Credit Rating and Low Analyst Following. Small Borrower is an indicator variable equal to 1 if borrower size is below the sample median, and 0 otherwise. No Credit Rating is an indicator variable equal to 1 if $\mathrm{S} \& \mathrm{P}$ domestic long-term issuer credit rating is not available for the firm, and 0 otherwise. Low Analyst Following is an indicator variable equal to 1 if the number of analyst forecasts of the borrower's annual earnings per share the year before loan origination is below sample median, and 0 otherwise. I include these variables as the main effect and interact them with $P B R$ and $P L R \cdot{ }^{23}$ My focus is on the interaction terms.

Across Columns 1-3, consistent with H2.1, I find that the effect of PBR on participants' share is more pronounced for opaque borrowers. In particular, as shown in Column 1, while PBR increases participants' share in the loan by $0.57 \%$ for large borrowers (an $8 \%$ increase relative to the mean participant share of $6.83 \%$ ), the increase is significantly larger, by $63 \%$, for small borrowers (the coefficient on the interaction term is $0.36 \%$, compared with the main effect of 0.57\%). Similarly, in Column 2, I find that the effect of PBR on the participant's share is more pronounced for borrowers with no credit rating. While PBR increases participants' share in the loan by $0.61 \%$ for borrowers with a credit rating, the increase is significantly larger, by $35 \%$, for borrowers with no credit rating. Finally, in Column 3, I find that the effect of PBR is more pronounced for borrowers with low analyst following. While PBR increases participants' share in

\footnotetext{
${ }^{23}$ When I include Small Borrower, I no longer include Borrower Size among the other control variables.
} 
the loan by $0.61 \%$ for borrowers with the high analyst following, the increase is significantly, larger, by $30 \%$, for borrowers with the low analyst following.

In contrast, the association between PLR and participants' share does not differ between large and small borrowers, or between borrowers with the low and high analyst following, and is actually lower for borrowers with no credit rating, suggesting that, overall, borrowers' information opacity does not enhance the effect of PLR on participants' share in the loan.

Second, as noted in H2.2, I predict that the effect of PBR on participants' share is stronger for borrowers that are less conservative. In Panel B, I examine accounting conservatism using the firm-year conservatism score in Khan and Watts (2009). Less Conservative Borrower is an indicator variable equal to 1 if the borrower's conservatism score is below the sample median, and 0 otherwise. Consistent with H2.2, I find that the effect of PBR on participants' share is more pronounced for less conservative borrowers. In particular, while PBR increases participants' share in the loan by $0.58 \%$ for conservative borrowers (an $8 \%$ increase relative to the mean participant share of $6.83 \%$ ), the increase is significantly larger, by $28 \%$, for less conservative borrowers (the coefficient on the interaction term is $0.16 \%$, compared with the main effect of $0.58 \%$ ). In contrast, the association between PLR and participants' share does not differ for different levels of accounting conservatism, suggesting that, borrower accounting conservatism does not impact PLR's effect on participants' share in the loan.

Third, as predicted in $H 2.3$, I expect that the effect of PLR on participants' share is stronger for borrowers with past accounting irregularities. In Panel C, Column 1, I examine accounting irregularities using AAER data obtained from the Berkeley Center for Financial Reporting and Management. AAER is an indicator variable equal to 1 if the SEC issued any Accounting and Audit Enforcement Releases for the borrower within 5 years prior to loan initiation. In Column 2, I 
examine material restatements from Audit Analytics. Restatement is an indicator variable equal to 1 if the borrower has restated the financial statements within 5 years prior to loan initiation, and 0 otherwise. Consistent with H2.3, I find that the effect of PLR on participants' share is more pronounced for borrowers with accounting irregularities. In particular, in Column 1, while PLR increases participants' share in the loan by $0.61 \%$ for borrowers without $A A E R$ (a $9 \%$ increase relative to the mean participant share of $6.83 \%$ ), the increase is significantly larger, by $118 \%$, for borrowers with $A A E R$ (the coefficient on the interaction term is $0.72 \%$, compared with the main effect of $0.61 \%$ ). In Column 2, while PLR increases participants' share in the loan by $0.59 \%$ for borrowers without Restatement (a 9\% increase relative to the mean participant share of $6.83 \%$ ), the increase is significantly larger, by $86 \%$, for borrowers with Restatement (the coefficient on the interaction term is $0.51 \%$, compared with the main effect of $0.59 \%$ ). In contrast, the association between PBR and participants' share does not differ for borrowers with accounting irregularities.

Fourth, as predicted in $H 2.4$, I expect that the effect of PLR on participants' share is stronger for borrowers with past covenant violations. In Panel D, I examine covenant violation data obtained from Amir Sufi's website following Nini et al. (2012). Covenant Violation is an indicator variable equal to 1 if the borrower has violated a loan covenant within 5 years prior to loan initiation and 0 otherwise. Consistent with $H 2.4$, I find that the effect of PLR on participants' share is more pronounced for borrowers with covenant violations. In particular, in Column 1, while PLR increases participants' share in the loan by $0.6 \%$ for borrowers without Covenant Violation (a $9 \%$ increase relative to the mean participant share of $6.83 \%$ ), the increase is significantly larger, by $105 \%$, for borrowers with Covenant Violation (the coefficient on the interaction term is $0.63 \%$, compared with the main effect of $0.6 \%$ ). In contrast, the association between PBR and participants' share is not affected by past covenant violations. 


\subsubsection{Cross-Sectional Determinants: Lead Arranger Characteristics}

Next, in Table 4, I examine how lead arrangers' characteristics influence the effect of PLR on participants' share. For this purpose, I examine two characteristics, Repeat Lead Arranger and Large Lead Arranger (defined as in Table 2) and include them in the regression both as main effects and as interaction terms with $P B R$ and $P L R$.

I find that lead arrangers' characteristics have a strong impact on the association between PLR and participants' share. In particular, as predicted in $H 3$, the effect of PLR on participants' share in the loan is higher in presence of a repeat lead arranger or a large lead arranger. As shown in Column 1, while PLR increases participants' share in the loan by $0.51 \%$ for loans with no repeat lead arranger, the increase is significantly larger, by $67 \%$, for loans with a repeat lead arranger. Similarly, in Column 2, while PLR increases participants' share in the loan by $0.51 \%$ for loans with no large lead arranger, the increase is significantly larger, by $70 \%$, for loans with a large lead arranger.

As for PBR, the interaction terms with Repeat Large Arranger is positive and significant, whereas the interaction term with Large Lead Arranger is not significant, providing only some evidence that lead arranger's characteristics influence the effect of PBR on participants' share.

\subsubsection{Cross-Sectional Determinants: Participant Characteristics}

Finally, in Table 5, I investigate the effect of participants' characteristics on the relationship between participant-level relationship lending (as proxied by $P B R$ and $P L R$ ) and participants' share. In particular, I focus on two proxies for participants' information acquisition capacity limits:

Small Participant Bank, an indicator variable equal to 1 if total assets of the participant bank are 
below sample median, and 0 otherwise; and Faster Loan Growth Bank, an indicator variable equal to 1 if loan growth rate of the participant bank is above sample median, and 0 otherwise. ${ }^{24}$

I find that while PLR does not increase participants' share for large participant banks, it increases participants' share for small participant banks, and the difference (as captured by the interaction term) is statistically significant (Column 1). Similarly, in Column 2, while PLR increases participants' share in the loan by $0.68 \%$ for a slower loan growth participant bank, the increase is significantly larger, by $103 \%$, for a faster loan growth participant bank.

Overall, these results are consistent with the notion that when participants have information acquisition capacity limits, the effect of PLR on participants' share is more pronounced, consistent with the prediction in $H 5$. In contrast, the effect of PBR on participants' share is not significantly different between small and larger participant banks, or between faster and slower loan growth participant banks.

\subsection{Loan Syndicate Structure}

The previous analyses focus on individual participants' share decisions, that is, at the package-participant level. My next analyses examine the effect of participant-level relationship lending (PBR and PLR) on the loan syndicate structure at the package level.

In particular, in Table 6, I analyze how Total PBR Share and Total PLR Share for a loan package impact two measures of loan syndicate structure: Lead Arranger Share and loan concentration index (Herfindahl Index). ${ }^{25}$ In $\mathrm{H} 5$, I predict that participant-level relationship lending will reduce the need for a larger lead arranger's share or for greater loan concentration.

\footnotetext{
${ }^{24}$ The sample observations drop to 11,329 and 11,294 because this table requires participant financial information from Bank Compustat.

${ }^{25}$ These measures are commonly used in studies on loan syndicate structure (e.g., Sufi 2007). In my setting, a benefit of examining the Herfindahl Index is that it suffers less from a potential mechanical relationship between participants' share and lead arrangers' share.
} 
Consistent with my hypothesis, I find a negative association between both Total PBR Share and Total PLR Share and the two variables of interest. In particular, one standard deviation increase in Total PBR Share decreases Lead Arranger Share by $0.75 \%(=0.028 * 26.87)$ while one standard deviation increase in Total PLR Share decreases Lead Arranger Share by 4.8\% (=0.172*27.91). As for the Herfindahl Index (Column 2), one standard deviation increase in Total PBR Share decreases Herfindahl Index by $55(=2.05 * 26.87)$, while one standard deviation increase in Total PLR Share decreases Herfindahl Index by $418.4(=14.99 * 27.91)$. The stronger effect of Total PLR Share may be viewed as evidence that participants' relationships with lead arrangers play a stronger role in mitigating information asymmetry problems.

\subsection{Cost of Debt}

In Table 7, I test $H 6$ by examining whether participant-level relationship lending (PBR and PLR) reduces demand for information asymmetry compensation, as proxied by Loan Spread, and reduces syndication cost and syndication risk, as proxied by Upfront Fee. My first dependent variable is Loan Spread, measured as the amount a borrower pays in basis points over LIBOR for each dollar drawn down including any annual fees. Consistent with my prediction, I find a negative association between participant-level relationship lending (Total PBR Share and Total PLR Share) and the loan spread. In particular, one standard deviation increase in Total PBR Share decreases Loan Spread by $1.7\left(=0.065^{*} 26.87\right)$ basis points, and one standard deviation increase in Total PLR

Share decreases Loan Spread by $17.3(=0.619 * 27.91)$ basis points. To assess the economic magnitude of these effects, consider that the average syndicated loan in my sample has a loan spread of 146 basis points. Also, prior studies document that a lead arranger relationship with the borrower is associated with a decrease of 10 to 17 basis points in the loan spread (Bharath et al. 2011). Similar to Table 6, the stronger effect of Total PLR Share may suggest that participants' 
relationships with lead arrangers play a stronger role in mitigating information asymmetry problems.

My second dependent variable is Upfront Fee, measured as the one-time fee paid by the borrower to lenders at loan initiation. Consistent with my prediction, for the 1,964 facilities with available upfront fee information, I find a negative association between participant-lead arranger relationship (Total PLR Share) and upfront fee. In particular, one standard deviation increase in Total PLR Share decreases Upfront Fee by $5.8(=0.209 * 27.91)$ basis points, a $14 \%$ increase compared with the average upfront fee. However, Total PBR Share has no effect on Upfront Fee. This test suggests that PLR plays a more important role in decreasing loan syndication cost and loan syndication risk.

\subsection{Incomplete Contracting}

Finally, in Table 8, I provide exploratory analyses on how participant-level relationship lending impacts incomplete debt contracting. Incomplete debt contracting refers to the situation in which lenders worry about future realizations and cannot contract ex-ante for each future state. So they use renegotiation, performance pricing and other contracting features to help them allocate control rights and better contract for uncertainty in the future (Christensen et al. 2015).

I identify renegotiations using Dealscan loan amendment data, which include syndicated loan renegotiations that require a lender majority vote (Nikolaev 2013). There are loan renegotiations in 1139 of the 5989 packages in my sample. I create an indicator variable called Renegotiation to identify these cases and use it as a dependent variable. In Column 1, using a logit regression, I find a positive significant coefficient on Total PLR share. That is, a loan package with more influence of PLR participants is more likely to be renegotiated, consistent with PLR 
lowering renegotiation costs (assuming that the ex-post deal amendment is a proxy for the ex-ante difficulty in obtaining a lender majority vote).

Next, I use Dealscan performance pricing data to identify (i) interest-increase-only performance pricing and (ii) interest-decrease-only performance pricing. Following Asquith et al. (2005), interest-increase-only performance pricing captures concerns with the moral hazard problem, because lenders who suffer from the moral hazard problem want to retain the right to increase the interest if lead arrangers or borrowers shirk. Interest-decrease-only performance pricing captures concerns with the adverse selection problem, because lenders who suffer from adverse selection problem and require a higher loan spread, may give the borrower a chance to reduce the loan spread ex-post. In my sample, 5056 of the 7688 facilities have performance pricing data available. Of this subset, in $27.5 \%$ of the cases, the performance pricing grids have the interest increasing only pricing grid (a proxy for high concern with moral hazard), while $9.5 \%$ have the interest decreasing only pricing grid (a proxy for high concern with adverse selection). To identify these cases, I create two indicator variables, respectively, Interest Increasing PP and Interest Decreasing PP, which I use as dependent variables. In Column 2, using a logit regression, I find a positive significant coefficient on Total PBR Share, suggesting that participants with a borrower relationship cannot mitigate moral hazard because they do not know the lead arranger well. The negative significant coefficient on Total PLR Share indicates that participants with a lead arranger relationship can better mitigate moral hazard, because they know the lead arranger's monitoring ability.

In Column 3, the negative significant coefficient on Total PBR Share indicates that participants with a borrower relationship can better mitigate adverse selection, because they know the borrower well. The insignificant coefficient on Total PLR Share suggests that participants with 
a lead arranger relationship cannot really mitigate adverse selection, because they have less information about the borrower.

Overall, I interpret the performance pricing result as preliminary evidence that PLR helps to reduce moral hazard in terms of the effort in lead arrangers' monitoring and due diligence, while PBR helps to mitigate the signaling problem with respect to adverse selection.

\section{Conclusion}

As prior literature extensively examines relationship lead arrangers in syndicated loans, recent studies begin to look at the role of relationship participants. I provide novel evidence on how participants' relationships with firms and lead arrangers impact the participants' share in the loan. Specifically, I find that participants with a borrower relationship take, on average, a 10\% larger share, while participants with a lead arranger relationship take, on average, a 9\% larger share. Furthermore, I identify the economic factors associated with the greater importance of PBR and PLR. Specifically, when borrower information is opaque or when the borrower is less conservative, the effect of PBR is more pronounced. In contrast, when the borrower has prior accounting irregularities or covenant violations, when the lead arranger is a repeat lender or a large lender, and when participants have information acquisition capacity limits, the effect of PLR is more pronounced. Additional analyses show that loans with a larger share taken by relationship participants are associated with a smaller lead arranger share, a less concentrated loan syndicate, a lower cost of debt and a lower cost of incomplete contracting.

My paper contributes to the interaction of relationship lending and syndicated lending literature. My initial evidence on the role of PBR and PLR in syndicated lending opens up additional questions. For example, do institutional relationship participants profit more in stock 
trading? In addition, do relationship participants benefit by future loan deals or cross-selling opportunities? 


\section{Table 1: Sample Selection and Descriptive Statistics}

This table presents the sample selection process and descriptive statistics. Variables are defined in Appendix A.

Panel A: Sample Selection

\section{Sample Selection Step}

Loan packages

Compustat U.S. non-financial firms from 1990 to 2012

41,309

Lead arranger and participant information

25,678

At least one loan in prior 5 years for the same borrower

18,783

Loan share and loan spread information

6,643

Borrower-level variables information

5,989

Panel B: Descriptive Statistics

\begin{tabular}{|c|c|c|c|c|c|c|}
\hline & & & & \multicolumn{3}{|c|}{ Distribution } \\
\hline Variables & $\mathrm{N}$ & Mean & SD & P10 & P50 & $\mathrm{P} 90$ \\
\hline \multicolumn{7}{|l|}{ Primary Dependent Variable } \\
\hline Participant Share & 61,373 & 6.83 & 6.24 & 1.61 & 5 & 13.89 \\
\hline \multicolumn{7}{|l|}{ Variables of Interest } \\
\hline$P B R$ & 61,373 & 0.41 & 0.49 & 0 & 0 & 1 \\
\hline$P L R$ & 61,373 & 0.84 & 0.36 & 0 & 1 & 1 \\
\hline \multicolumn{7}{|l|}{ Participant-Level Variables } \\
\hline Industry Exposure & 61,373 & 0.35 & 0.48 & 0 & 0 & 1 \\
\hline Lender Type & 61,373 & 0.8 & 0.4 & 0 & 1 & 1 \\
\hline \multicolumn{7}{|l|}{ Borrower-Level Variables } \\
\hline Borrower Size $e^{26}$ & 2,314 & $4,559.34$ & $12,314.79$ & 156.95 & 873.97 & $10,604.59$ \\
\hline Profitability & 2,314 & 0.03 & 0.08 & -0.05 & 0.04 & 0.11 \\
\hline Leverage & 2,314 & 0.26 & 0.19 & 0.02 & 0.24 & 0.51 \\
\hline Tangibility & 2,314 & 0.37 & 0.25 & 0.08 & 0.31 & 0.76 \\
\hline Credit Rating Availability & 2,314 & 0.47 & 0.5 & 0 & 0 & 1 \\
\hline \multicolumn{7}{|l|}{ Package-Level Variables } \\
\hline Lead Arranger Share & 5,989 & 21.1 & 14.91 & 6.67 & 16.25 & 48 \\
\hline Repeat Lead Arranger & 5,989 & 0.37 & 0.48 & 0 & 0 & 1 \\
\hline Large Lead Arranger & 5,989 & 0.45 & 0.5 & 0 & 0 & 1 \\
\hline Number of Lead Arrangers & 5,989 & 1.58 & 1.53 & 1 & 1 & 2 \\
\hline Number of Participants & 5,989 & 10.25 & 9.05 & 2 & 8 & 22 \\
\hline Total PBR Share & 5,989 & 28.17 & 26.87 & 0 & 24.16 & 67.29 \\
\hline Total PLR Share & 5,989 & 56.82 & 27.91 & 6.92 & 64.09 & 86.85 \\
\hline \multicolumn{7}{|l|}{ Facility-Level Variables } \\
\hline Loan Spread & 7,688 & 146.04 & 106.51 & 30 & 125 & 300 \\
\hline Upfront Fee & 1,964 & 42.67 & 50.10 & 7.5 & 25 & 100 \\
\hline Loan maturity & 7,688 & 45.16 & 22.15 & 12 & 48 & 69 \\
\hline Secured Loan & 7,688 & 0.42 & 0.49 & 0 & 0 & 1 \\
\hline
\end{tabular}


Panel C: Top 5 Relationship Intensive Participants

\begin{tabular}{lc}
\hline Top 5 Borrower Relationship Intensive Participants & $\begin{array}{c}\text { Average Number of Prior Loans } \\
\text { with the Same Borrower }\end{array}$ \\
\hline Bank of New York & 1.41 \\
Societe Generale & 1.38 \\
Mellon Bank & 1.34 \\
Barclays Bank Plc & 1.30 \\
Bank of Nova Scotia & 1.25 \\
\hline & Average Number of Prior Loans \\
Top 5 Lead Arranger Relationship Intensive Participants & with the Same Lead Arranger \\
\hline US Bank & 191 \\
Bank of New York & 145 \\
SunTrust Bank & 124 \\
BNP Paribas & 114 \\
Bank of Nova Scotia & 103 \\
\hline
\end{tabular}




\section{Table 2: The Effect of PBR and PLR on Participants' Share in the Loan}

This table analyzes the effect of PBR and PLR on a participant's share in the loan. The dependent variable is Participant Share. All variables are defined in Appendix A. Standard errors reported in parentheses are corrected for heteroscedasticity and firm-level clustering. ${ }^{* *}, * *$ and $*$ indicate significance at the $0.01,0.05,0.10$ levels, respectively.

\begin{tabular}{|c|c|c|}
\hline & \multicolumn{2}{|c|}{$\begin{array}{c}\text { Dependent Variable: } \\
\text { Participant Share }\end{array}$} \\
\hline$P B R$ & $\begin{array}{l}0.739 * * * \\
(0.039)\end{array}$ & $\begin{array}{c}0.668 * * * \\
(0.047)\end{array}$ \\
\hline$P L R$ & $\begin{array}{l}0.951 * * * \\
(0.064)\end{array}$ & $\begin{array}{c}0.633 * * * \\
(0.081)\end{array}$ \\
\hline Industry Exposure & $\begin{array}{c}0.043 \\
(0.048)\end{array}$ & $\begin{array}{c}0.073 \\
(0.057)\end{array}$ \\
\hline Lender Type & $\begin{array}{c}0.096 * * \\
(0.049)\end{array}$ & $\begin{array}{l}0.098 * \\
(0.059)\end{array}$ \\
\hline Borrower Size & & $\begin{array}{c}-0.395 * * * \\
(0.149)\end{array}$ \\
\hline Profitability & & $\begin{array}{l}-1.722 * \\
(0.956)\end{array}$ \\
\hline Leverage & & $\begin{array}{l}-0.691 \\
(0.558)\end{array}$ \\
\hline Tangibility & & $\begin{array}{l}1.488 * * \\
(0.743)\end{array}$ \\
\hline Credit Rating Availability & & $\begin{array}{c}-0.538 * * * \\
(0.153)\end{array}$ \\
\hline Lead Arranger Share & & $\begin{array}{c}0.108 * * * \\
(0.012)\end{array}$ \\
\hline Repeat Lead Arranger & & $\begin{array}{l}-0.071 \\
(0.088)\end{array}$ \\
\hline Large Lead Arranger & & $\begin{array}{c}-0.427 * * * \\
(0.111)\end{array}$ \\
\hline Number of Lead Arrangers & & $\begin{array}{c}-0.966 * * * \\
(0.102)\end{array}$ \\
\hline Number of Participants & & $\begin{array}{c}-0.180 * * * \\
(0.018)\end{array}$ \\
\hline Constant & $\begin{array}{l}4.201 * * * \\
(0.467)\end{array}$ & $\begin{array}{c}14.416 * * * \\
(1.238)\end{array}$ \\
\hline Package Fixed Effect & Yes & No \\
\hline Borrower Fixed Effect & No & Yes \\
\hline Year Fixed Effect & Yes & Yes \\
\hline Observations & 61,373 & 61,373 \\
\hline$R$-squared & 0.803 & 0.666 \\
\hline
\end{tabular}




\section{Table 3: Borrower Characteristics and the Effect of PBR and PLR on Participants' Share in the Loan}

This table examines how borrower characteristics influences the effect of PBR and PLR on participants' share in the loan. Panel A examines borrower information opacity. Column 1 presents the analyses based on borrower size, where Small Borrower is an indicator variable equal to 1 if the borrower size is below sample median, and 0 otherwise. Column 2 presents the analyses based on credit rating availability, where No Credit Rating is an indicator variable equal to 1 if S\&P domestic long-term issuer credit rating is not available for the firm, and 0 otherwise. Column 3 presents the analyses based on analyst following intensity, where Low Analyst Following is an indicator variable equal to 1 if the number of analyst forecasts on borrowers' annual earnings per share the year before loan origination is below sample median, and 0 otherwise. Panel B examines borrowers' accounting conservatism, where Less Conservative Borrower is an indicator variable equal to 1 if the borrower's conservatism score constructed following Khan and Watts (2009) is below the sample median, and 0 otherwise. Panel C examines borrowers' accounting irregularities. In Column 1, AAER is an indicator variable equal to 1 if the SEC issued any Accounting and Audit Enforcement Releases for the borrower within 5 years prior to loan initiation, and 0 otherwise. In Column 2 , Restatement is an indicator variable equal to 1 if the borrower has restated the financial statements within 5 years prior to loan initiation, and 0 otherwise. Panel D examines borrowers' past loan performances by covenant violations. Covenant Violation is an indicator variable equal to 1 if the borrower has violated at least one loan covenant within 5 years prior to loan initiation, and 0 otherwise. All other variables are defined in Appendix A. Standard errors reported in parentheses are corrected for heteroscedasticity. $* * *, * *$ and $*$ indicate significance at the $0.01,0.05,0.10$ levels, respectively.

Panel A: Borrower Information Opacity

\begin{tabular}{lccc}
\hline \multicolumn{3}{c}{ Dependent Variable: } \\
\hline & Pmall & No Credit & Low Analyst \\
& Borrower & Rating & Following \\
\hline$P B R$ & $0.567^{* * *}$ & $0.612^{* * *}$ & $0.605^{* * *}$ \\
& $(0.047)$ & $(0.051)$ & $(0.054)$ \\
$P L R$ & $0.714^{* * *}$ & $0.767^{* * *}$ & $0.653^{* * *}$ \\
& $(0.099)$ & $(0.095)$ & $(0.109)$ \\
$P B R^{*}$ Opaque Borrower & $0.359^{* * *}$ & $0.216^{*}$ & $0.183^{*}$ \\
& $(0.123)$ & $(0.122)$ & $(0.099)$ \\
PLR*Opaque Borrower & -0.180 & $-0.374^{* *}$ & -0.046 \\
& $(0.175)$ & $(0.185)$ & $(0.166)$ \\
Opaque Borrower & $0.426 *$ & $0.761 * * *$ & -0.045 \\
& $(0.256)$ & $(0.220)$ & $(0.229)$ \\
Participant, Borrower and Package Level Controls & Yes & Yes & Yes \\
Borrower Fixed Effect & Yes & Yes & Yes \\
Year Fixed Effect & Yes & Yes & Yes \\
Observations & 61,373 & 61,373 & 61,373 \\
$R$-squared & 0.666 & 0.666 & 0.666 \\
\hline
\end{tabular}


Panel B: Borrowers' Accounting Conservatism

\begin{tabular}{lc}
\hline & $\begin{array}{c}\text { Dependent Variable: } \\
\text { Participant Share }\end{array}$ \\
\hline$P B R$ & $0.583^{* * *}$ \\
$P L R$ & $(0.042)$ \\
$P B R^{*}$ Less Conservative Borrower & $0.703^{* * *}$ \\
& $(0.077)$ \\
PLR* Less Conservative Borrower & $0.159 * *$ \\
& $(0.073)$ \\
Less Conservative Borrower & -0.114 \\
& $(0.123)$ \\
Participant, Borrower and Package Level Controls & $0.568^{* * *}$ \\
Borrower Fixed Effect & $(0.157)$ \\
Year Fixed Effect & $Y e s$ \\
Observations ${ }^{27}$ & $Y e s$ \\
R-squared & $Y e s$ \\
& 59,147 \\
\end{tabular}

Panel C: Borrowers' Accounting Irregularities

\begin{tabular}{lcc}
\hline & \multicolumn{2}{c}{ Dependent Variable: } \\
& Participant Share \\
\hline PBR & AAER & Restatement \\
PLR & $0.664 * * *$ & $0.664^{* * *}$ \\
& $(0.036)$ & $(0.037)$ \\
PBR* Borrower with Accounting Irregularity & $0.61 *^{* *}$ & $0.589 * * *$ \\
& $(0.061)$ & $(0.062)$ \\
PLR* Borrower with Accounting Irregularity & -0.194 & -0.085 \\
& $(0.153)$ & $(0.110)$ \\
Borrower with Accounting Irregularity & $0.717^{*}$ & $0.506^{* *}$ \\
& $(0.316)$ & $(0.226)$ \\
Participant, Borrower and Package Level Controls & $-1.27 * * *$ & -0.286 \\
Borrower Fixed Effect & $(0.334)$ & $(0.230)$ \\
Year Fixed Effect & $Y e s$ & Yes \\
Observations & $Y e s$ & Yes \\
$R$-squared & Yes & Yes \\
\hline
\end{tabular}

\footnotetext{
${ }^{27}$ The observation is lower than 61,373 because conservatism score requires the availability of an additional firm
} variable (Market-to-Book Ratio). 
Dependent Variable:

Participant Share

\begin{tabular}{lc}
\hline PBR & $0.649^{* * *}$ \\
$P L R$ & $(0.035)$ \\
& $0.596^{* * *}$ \\
PBR* Covenant Violation & $(0.061)$ \\
& 0.088 \\
PLR* Covenant Violation & $(0.194)$ \\
& $0.631^{* *}$ \\
Covenant Violation & $(0.311)$ \\
& -0.072 \\
Participant, Borrower and Package Level Controls & $(0.327)$ \\
Borrower Fixed Effect & $Y e s$ \\
Year Fixed Effect & $Y e s$ \\
Observations & $Y e s$ \\
$R$-squared & 61,373 \\
\hline
\end{tabular}




\section{Table 4: Lead Arranger Characteristics and the Effect of PBR and PLR on Participants' Share in the Loan}

This table investigates how lead arranger characteristics influence the effect of PBR and PLR on participants' share in the loan. Column 1 presents the analyses based on Repeat Lead Arranger. Column 2 presents the analyses based on Large Lead Arranger. All variables are defined in Appendix A. Standard errors reported in parentheses are corrected for heteroscedasticity and firm-level clustering. $* * *, * *$ and $*$ indicate significance at the $0.01,0.05,0.10$ levels, respectively.

\begin{tabular}{lcc}
\hline & \multicolumn{2}{c}{$\begin{array}{c}\text { Dependent Variable: } \\
\text { Participant share }\end{array}$} \\
\hline PBR & Repeat Lead & Large Lead \\
& Arranger & Arranger \\
$P L R$ & $0.529 * * *$ & $0.683^{* * *}$ \\
& $(0.069)$ & $(0.075)$ \\
$P B R^{*}$ Lead Arranger Characteristics & $0.509 * * *$ & $0.513^{* * *}$ \\
& $(0.111)$ & $(0.108)$ \\
PLR* Lead Arranger Characteristics & $0.277 * * *$ & -0.030 \\
& $(0.093)$ & $(0.092)$ \\
Lead Arranger Characteristics & $0.345 *$ & $0.359^{* *}$ \\
& $(0.185)$ & $(0.164)$ \\
Participant, Borrower and Package Level Controls & $-0.502^{* *}$ & $-0.728^{* * *}$ \\
Borrower Fixed Effect & $(0.207)$ & $(0.203)$ \\
Year Fixed Effect & Yes & Yes \\
Observations & Yes & Yes \\
$R$-squared & Yes & Yes \\
\hline
\end{tabular}




\section{Table 5: Participant Characteristics and the Effect of PBR and PLR on Participants' Share in the Loan}

This table analyzes how participant bank characteristics influence the effect of PBR and PLR on participants' share in the loan. Column 1 presents the analyses based on participant bank size, where Small Participant Bank is an indicator variable equal to 1 if total assets of the participant bank is below sample median, and 0 otherwise. Column 2 presents the analyses based on the participant bank's loan growth rate, where Faster Loan Growth Bank is an indicator variable equal to 1 if loan growth rate of the participant bank is above sample median, and 0 otherwise. All other variables are defined in Appendix A. Standard errors reported in parentheses are corrected for heteroscedasticity. $* * *, * *$ and $*$ indicate significance at the $0.01,0.05,0.10$ levels, respectively.

\begin{tabular}{lcc}
\hline & Dependent Variable: Participant Share \\
\hline & Small Participant & Faster Loan Growth \\
& Bank & $0.718^{* * *}$ \\
\hline PBR & $0.737 * * *$ & $(0.102)$ \\
$P L R$ & $(0.090)$ & $0.680^{* * *}$ \\
& 0.249 & $(0.243)$ \\
PBR* Participant Characteristics & $(0.277)$ & 0.116 \\
& -0.074 & $(0.146)$ \\
PLR* Participant Characteristics & $(0.165)$ & $0.703^{* *}$ \\
& $1.019^{* * *}$ & $(0.306)$ \\
Participant Characteristics & $(0.322)$ & $-0.652^{* *}$ \\
& $-2.227 * * *$ & $(0.301)$ \\
Participant, Borrower and Package Level Controls & $(0.312)$ & Yes \\
Borrower Fixed Effect & $Y e s$ & Yes \\
Year Fixed Effect & Yes & Yes \\
Observations & Yes & 11,294 \\
R-squared & 11,329 & 0.765 \\
\hline
\end{tabular}




\section{Table 6: The Effect of PBR and PLR on Loan Syndicate Structure}

This table analyzes how Total PBR Share and Total PLR Share for a loan package impact lead arrangers' share and loan concentration index (Herfindahl Index). Standard errors reported in parentheses are corrected for heteroscedasticity and firm-level clustering. $* * *, * *$ and $*$ indicate significance at the $0.01,0.05,0.10$ levels, respectively. All variables are defined in Appendix A.

\begin{tabular}{|c|c|c|}
\hline & \multicolumn{2}{|c|}{ Dependent Variables } \\
\hline & Lead Arranger Share & Herfindahl Index \\
\hline \multirow[t]{2}{*}{ Total PBR Share } & $-0.028 * * *$ & $-2.052 * * *$ \\
\hline & $(0.008)$ & $(0.609)$ \\
\hline \multirow[t]{2}{*}{ Total PLR Share } & $-0.172 * * *$ & $-14.990 * * *$ \\
\hline & $(0.014)$ & $(1.229)$ \\
\hline \multirow{2}{*}{ Borrower Size } & $-1.775^{* * *}$ & $-140.093 * * *$ \\
\hline & $(0.257)$ & $(23.414)$ \\
\hline \multirow[t]{2}{*}{ Profitability } & $-6.906 * * *$ & $-1,121.23 * * *$ \\
\hline & $(2.361)$ & $(202.275)$ \\
\hline \multirow[t]{2}{*}{ Leverage } & $-2.157 *$ & -163.379 \\
\hline & $(1.170)$ & $(103.883)$ \\
\hline \multirow[t]{2}{*}{ Tangibility } & -1.601 & -148.276 \\
\hline & $(1.188)$ & (111.577) \\
\hline \multirow[t]{2}{*}{ Credit Rating Availability } & $-0.983 * *$ & $-77.753 * *$ \\
\hline & $(0.483)$ & $(35.460)$ \\
\hline \multirow[t]{2}{*}{ Repeat Lead Arranger } & 0.403 & 0.021 \\
\hline & $(0.332)$ & $(26.682)$ \\
\hline \multirow[t]{2}{*}{ Large Lead Arranger } & $1.551 * * *$ & $122.503 * * *$ \\
\hline & $(0.342)$ & $(28.130)$ \\
\hline \multirow{2}{*}{ Number of Lead Arrangers } & $-1.977 * * *$ & $-148.284 * * *$ \\
\hline & $(0.184)$ & $(14.658)$ \\
\hline \multirow[t]{2}{*}{ Number of Participants } & $-0.520 * * *$ & $-52.209 * * *$ \\
\hline & $(0.054)$ & $(4.765)$ \\
\hline \multirow[t]{2}{*}{ Constant } & $54.166^{* * *}$ & $4,591.570 * * *$ \\
\hline & $(2.092)$ & $(210.312)$ \\
\hline Industry Fixed Effect & Yes & Yes \\
\hline Year Fixed Effect & Yes & Yes \\
\hline Observations & 5,989 & 5,989 \\
\hline$R$-squared & 0.555 & 0.571 \\
\hline
\end{tabular}




\section{Table 7: The Effect of PBR and PLR on Cost of Debt}

This table analyzes how Total PBR Share and Total PLR Share impact cost of debt (Loan Spread and Upfront fee). Standard errors reported in parentheses are corrected for heteroscedasticity. ***,** and * indicate significance at the $0.01,0.05,0.10$ levels, respectively. All variables are defined in Appendix A.

\begin{tabular}{|c|c|c|}
\hline & \multicolumn{2}{|c|}{ Dependent Variable } \\
\hline & Loan Spread & Upfront Fee \\
\hline \multirow[t]{2}{*}{ Total PBR Share } & $-0.065^{*}$ & -0.019 \\
\hline & $(0.038)$ & $(0.045)$ \\
\hline \multirow[t]{2}{*}{ Total PLR Share } & $-0.619 * * *$ & $-0.209 * * *$ \\
\hline & $(0.045)$ & $(0.040)$ \\
\hline \multirow[t]{2}{*}{ Borrower Size } & $-18.982 * * *$ & -0.481 \\
\hline & $(1.016)$ & $(1.148)$ \\
\hline \multirow{2}{*}{ Profitability } & $-314.484 * * *$ & $-104.388 * * *$ \\
\hline & $(16.197)$ & $(13.911)$ \\
\hline \multirow[t]{2}{*}{ Leverage } & $80.658 * * *$ & 1.341 \\
\hline & $(5.821)$ & $(6.483)$ \\
\hline \multirow[t]{2}{*}{ Tangibility } & $-27.432 * * *$ & -0.417 \\
\hline & $(5.572)$ & $(6.007)$ \\
\hline \multirow[t]{2}{*}{ Credit Rating Availability } & 1.560 & $7.272 * * *$ \\
\hline & $(2.130)$ & $(2.493)$ \\
\hline \multirow[t]{2}{*}{ Repeat Lead Arranger } & -1.242 & -1.193 \\
\hline & $(1.854)$ & $(2.626)$ \\
\hline \multirow[t]{2}{*}{ Large Lead Arranger } & $5.680 * * *$ & -0.995 \\
\hline & $(1.802)$ & $(2.073)$ \\
\hline \multirow[t]{2}{*}{ Number of Lead Arrangers } & $-2.000 * * *$ & $-1.202 *$ \\
\hline & $(0.666)$ & $(0.617)$ \\
\hline \multirow[t]{2}{*}{ Number of Participants } & $0.726 * * *$ & $0.317 * * *$ \\
\hline & $(0.103)$ & $(0.116)$ \\
\hline \multirow[t]{2}{*}{ Loan Maturity } & $-0.161 * * *$ & 0.030 \\
\hline & $(0.047)$ & $(0.047)$ \\
\hline \multirow[t]{2}{*}{ Secured Loan } & $63.815 * * *$ & $19.605 * * *$ \\
\hline & $(2.292)$ & $(2.266)$ \\
\hline \multirow[t]{2}{*}{ Facility Size } & $-0.002 * * *$ & 0.000 \\
\hline & $(0.001)$ & $(0.002)$ \\
\hline \multirow[t]{2}{*}{ Constant } & $270.587 * * *$ & $55.310 * * *$ \\
\hline & $(11.039)$ & $(11.976)$ \\
\hline Industry Fixed Effect & Yes & Yes \\
\hline Year Fixed Effect & Yes & Yes \\
\hline Observations & 7,688 & 1,964 \\
\hline$R$-squared & 0.576 & 0.304 \\
\hline
\end{tabular}




\section{Table 8: The Effect of PBR and PLR on Incomplete Debt Contracting}

This table analyzes how Total PBR Share and Total PLR Share impact incomplete debt contracting. In Column 1, Renegotiation $=1$ when there is deal amendment for the loan, and 0 otherwise. In Column 2, Interest Increasing $P P=1$ when there is interest-increasing-only performance pricing for the facility, and 0 otherwise. In Column 3 , Interest decreasing $P P=1$ when there is interest-decreasing-only performance pricing for the facility, and 0 otherwise. All other variables are defined in Appendix A. Standard errors reported in parentheses are corrected for heteroscedasticity. $* * *, * *$ and $*$ indicate significance at the $0.01,0.05,0.10$ levels, respectively.

\begin{tabular}{|c|c|c|c|}
\hline & \multicolumn{3}{|c|}{ Dependent Variables } \\
\hline & Renegotiation & $\begin{array}{c}\text { Interest Increasing } \\
P P\end{array}$ & $\begin{array}{c}\text { Interest Decreasing } \\
P P\end{array}$ \\
\hline \multirow[t]{2}{*}{ Total PBR Share } & -0.001 & $0.003^{*}$ & $-0.007 * * *$ \\
\hline & $(0.002)$ & $(0.002)$ & $(0.003)$ \\
\hline \multirow[t]{2}{*}{ Total PLR Share } & $0.006 * * *$ & $-0.009 * * *$ & -0.002 \\
\hline & $(0.002)$ & $(0.002)$ & $(0.003)$ \\
\hline \multirow[t]{2}{*}{ Borrower Size } & $-0.211 * * *$ & $-0.463 * * *$ & $0.192 * * *$ \\
\hline & $(0.032)$ & $(0.045)$ & $(0.064)$ \\
\hline \multirow[t]{2}{*}{ Profitability } & $-0.857 * *$ & $-1.521 * * *$ & 1.427 \\
\hline & $(0.424)$ & $(0.575)$ & $(0.890)$ \\
\hline \multirow[t]{2}{*}{ Leverage } & -0.177 & $0.501 * *$ & $-2.620 * * *$ \\
\hline & $(0.200)$ & $(0.219)$ & $(0.403)$ \\
\hline \multirow[t]{2}{*}{ Tangibility } & -0.041 & $0.259 *$ & $0.708 * * *$ \\
\hline & $(0.136)$ & $(0.141)$ & $(0.216)$ \\
\hline \multirow{2}{*}{ Credit Rating Availability } & 0.057 & 0.017 & $-0.831 * * *$ \\
\hline & $(0.084)$ & $(0.093)$ & $(0.132)$ \\
\hline \multirow[t]{2}{*}{ Repeat Lead Arranger } & 0.083 & -0.005 & 0.140 \\
\hline & $(0.079)$ & $(0.082)$ & $(0.122)$ \\
\hline \multirow[t]{2}{*}{ Large Lead Arranger } & $-0.157 * *$ & $0.150^{*}$ & -0.016 \\
\hline & $(0.074)$ & $(0.079)$ & $(0.116)$ \\
\hline \multirow[t]{2}{*}{ Number of Lead Arrangers } & 0.035 & $-0.124 * *$ & 0.059 \\
\hline & $(0.029)$ & $(0.059)$ & $(0.039)$ \\
\hline \multirow[t]{2}{*}{ Number of Participants } & 0.006 & $0.029 * * *$ & $-0.032 * * *$ \\
\hline & $(0.005)$ & $(0.005)$ & $(0.009)$ \\
\hline \multirow[t]{2}{*}{ Loan Spread } & & $0.008 * * *$ & $-0.005 * * *$ \\
\hline & & $(0.001)$ & $(0.001)$ \\
\hline \multirow[t]{2}{*}{ Loan Maturity } & & $0.008 * * *$ & -0.004 \\
\hline & & $(0.002)$ & $(0.003)$ \\
\hline \multirow[t]{2}{*}{ Secured Loan } & & $-0.403 * * *$ & $1.319 * * *$ \\
\hline & & $(0.091)$ & $(0.145)$ \\
\hline \multirow{2}{*}{ Facility Size } & & $0.000 * * *$ & 0.000 \\
\hline & & $(0.000)$ & $(0.000)$ \\
\hline \multirow[t]{2}{*}{ Constant } & -0.252 & $0.944 * * *$ & $-2.360 * * *$ \\
\hline & $(0.194)$ & $(0.305)$ & $(0.474)$ \\
\hline Observations & 5,989 & 5,056 & 5,056 \\
\hline Model & Logit & Logit & Logit \\
\hline
\end{tabular}




\section{References}

Altunbaş, Y., and A. Kara. 2011. Why do banks join loan syndications? The case of participant banks. The Service Industries Journal 31 (7):1063-1074.

Amiram, D., W. H. Beaver, W. R. Landsman, and J. D. Zhao. 2016. The Effects of CDS Trading Initiation on the Ownership Structure of Syndicated Loans. Available at SSRN.

Asquith, P., A. Beatty, and J. Weber. 2005. Performance pricing in bank debt contracts. Journal of Accounting and Economics 40 (1):101-128.Ball, R., R. M. Bushman, and F. P. Vasvari. 2008. The debt-contracting value of accounting information and loan syndicate structure. Journal of accounting research 46 (2):247-287.

Berg, T., Saunders, A. and Steffen, S., 2015. The total cost of corporate borrowing in the loan market: Don't ignore the fees. The Journal of Finance.

Berger, A. N., and G. F. Udell. 1995. Relationship lending and lines of credit in small firm finance. Journal of business:351-381.

Bharath, S., S. Dahiya, A. Saunders, and A. Srinivasan. 2007. So what do I get? The bank's view of lending relationships. Journal of Financial Economics 85 (2):368-419.

Bharath, S. T., S. Dahiya, A. Saunders, and A. Srinivasan. 2011. Lending relationships and loan contract terms. Review of Financial Studies 24 (4):1141-1203.

Boot, A.W., 2000. Relationship banking: What do we know?. Journal of financial intermediation, 9(1), pp.7-25.

Bushman, R. M., and R. Wittenberg-Moerman. 2012. The role of bank reputation in "certifying" future performance implications of borrowers' accounting numbers. Journal of accounting research 50 (4):883-930.

Champagne, C., and L. Kryzanowski. 2007. Are current syndicated loan alliances related to past alliances? Journal of Banking \& Finance 31 (10):3145-3161.

Chaudhry, S. M., and S. Kleimeier. 2015. Lead arranger reputation and the structure of loan syndicates. Journal of International Financial Markets, Institutions and Money 38:116-126.

Chava, S., and M. R. Roberts. 2008. How does financing impact investment? The role of debt covenants. the Journal of Finance 63 (5):2085-2121.

Christensen, H. B., V. V. Nikolaev, and R. Wittenberg Moerman. 2015. Accounting information in financial contracting: The incomplete contract theory perspective. Chicago Booth Research Paper (15-45).

Dahiya, S., A. Saunders, and A. Srinivasan. 2003. Financial distress and bank lending relationships. the Journal of Finance 58 (1):375-399.

Dechow, P. M., R. G. Sloan, and A. P. Sweeney. 1996. Causes and consequences of earnings misstatement: An analysis of firms subject to enforcement actions by the SEC. Contemporary Accounting Research 13 (1): 1-36.

Degryse, H., and P. Van Cayseele. 2000. Relationship lending within a bank-based system: Evidence from European small business data. Journal of Financial Intermediation 9 (1):90-109.

Dennis, S. A., and D. J. Mullineaux. 2000. Syndicated loans. Journal of Financial Intermediation 9 (4):404-426.

Diamond, D. W. 1984. Financial intermediation and delegated monitoring. The Review of Economic Studies 51 (3):393-414. 
Erkens, D.H., Subramanyam, K.R. and Zhang, J., 2014. Affiliated banker on board and conservative accounting. The Accounting Review, 89(5), pp.1703-1728.

Feroz, E.H., Park, K. and Pastena, V.S., 1991. The financial and market effects of the SEC's accounting and auditing enforcement releases. Journal of Accounting Research, pp.107-142.

François, P., and F. Missonier-Piera. 2007. The agency structure of loan syndicates. Financial Review 42 (2):227-245.

Gadanecz, B. 2004. The syndicated loan market: structure, development and implications. Available at SSRN.

Gadanecz, B., A. Kara, and P. Molyneux. 2012. Asymmetric information among lending syndicate members and the value of repeat lending. Journal of International Financial Markets, Institutions and Money 22 (4):913-935.

Graham, J.R., Li, S. and Qiu, J., 2008. Corporate misreporting and bank loan contracting. Journal of Financial Economics, 89(1), pp.44-61.Holmstrom, B. 1979. Moral hazard and observability. The Bell journal of economics:74-91.

Holmstrom, B., and J. Tirole. 1997. Financial intermediation, loanable funds, and the real sector. the Quarterly Journal of economics:663-691.

Ivashina, V. 2009. Asymmetric information effects on loan spreads. Journal of Financial Economics 92 (2):300-319.

Jones, J. D., W. W. Lang, and P. J. Nigro. 2005. Agent bank behavior in bank loan syndications. Journal of Financial Research 28 (3):385-402.

Khan, M. and Watts, R.L., 2009. Estimation and empirical properties of a firm-year measure of accounting conservatism. Journal of accounting and Economics, 48(2), pp.132-150.

Khan, U., X. Li, C. D. Williams, and R. Wittenberg Moerman. 2016. Co-Migration and the Benefits of Relationships in Bank Lending. Available at SSRN 2700514.

Lee, S. W., and D. J. Mullineaux. 2004. Monitoring, financial distress, and the structure of commercial lending syndicates. Financial Management:107-130.

Mansi, S. A., W. F. Maxwell, and D. P. Miller. 2011. Analyst forecast characteristics and the cost of debt. Review of Accounting Studies 16 (1):116-142.

Mugasha, A. 1998. Law of Multi-Bank Financing: McGill-Queen's Press-MQUP.

Nini, G., D. C. Smith, and A. Sufi. 2012. Creditor control rights, corporate governance, and firm value. Review of Financial Studies 25 (6): 1713-1761.

Nikolaev, V. V. 2013. Scope for renegotiation in private debt contracts. Available at SSRN 2012526.

Petersen, M. A., and R. G. Rajan. 1994. The benefits of lending relationships: Evidence from small business data. the Journal of Finance 49 (1):3-37.

Rajan, R. G. 1992. Insiders and outsiders: The choice between informed and arm's-length debt. the Journal of Finance 47 (4):1367-1400.

Rosenbaum, P., and D. Rubin. 1983. The central role of the propensity score in observational studies for causal effects. Biometrika 70 (1):41-55.

Roberts, M. R., and A. Sufi. 2009. Control rights and capital structure: An empirical investigation. Journal of Finance 64: 1657-95.

Simons, K. 1993. Why do banks syndicate loans? New England Economic Review (Jan):45-52. 
Sufi, A. 2007. Information asymmetry and financing arrangements: Evidence from syndicated loans. the Journal of Finance 62 (2):629-668.

Wittenberg-Moerman, R. 2008. The role of information asymmetry and financial reporting quality in debt trading: Evidence from the secondary loan market. Journal of Accounting and Economics 46 (2):240-260.

Zhang, J., 2008. The contracting benefits of accounting conservatism to lenders and borrowers. Journal of accounting and economics, 45(1), pp.27-54. 


\section{Appendix A: Variable Definitions}

\begin{tabular}{|c|c|}
\hline Variables & Definition \\
\hline \multicolumn{2}{|c|}{ Primary Dependent Variable } \\
\hline Participant Share & $\begin{array}{l}\text { The amount of the loan taken by a participant divided } \\
\text { by the total amount of the loan (Dealscan). }\end{array}$ \\
\hline \multicolumn{2}{|l|}{ Primary Variables of Interest } \\
\hline$P B R$ & $\begin{array}{l}\text { An indicator variable equal to } 1 \text { if the participant has } \\
\text { lent to the borrower within } 5 \text { years, and } 0 \text { otherwise } \\
\text { (Dealscan). }\end{array}$ \\
\hline$P L R$ & $\begin{array}{l}\text { An indicator variable equal to } 1 \text { if the participant has } \\
\text { joined the lead arranger's syndicate within } 5 \text { years } \\
\text { for any borrower, and } 0 \text { otherwise (Dealscan). }\end{array}$ \\
\hline \multicolumn{2}{|l|}{ Participant-Level Variables } \\
\hline Industry Exposure & $\begin{array}{l}\text { An indicator variable equal to } 1 \text { if the loan is within } \\
\text { top } 5 \text { industry that the participant has lent to within } \\
\text { prior } 3 \text { years, and } 0 \text { otherwise (Dealscan). }\end{array}$ \\
\hline Lender Type & $\begin{array}{l}\text { An indicator variable equal to } 1 \text { if the participant is a } \\
\text { depository institution, and } 0 \text { otherwise (Dealscan). }\end{array}$ \\
\hline \multicolumn{2}{|l|}{ Borrower-Level Variables } \\
\hline Borrower Size & $\begin{array}{l}\text { The natural logarithm of a borrower's total assets, } \\
\text { measured at the end of the most recent fiscal year } \\
\text { before loan origination (Compustat). }\end{array}$ \\
\hline Profitability & $\begin{array}{l}\text { The ratio of a borrower's net income before } \\
\text { extraordinary items to total assets, measured at the } \\
\text { end of the most recent fiscal year before loan } \\
\text { origination (Compustat). }\end{array}$ \\
\hline Leverage & $\begin{array}{l}\text { The ratio of a borrower's long-term debt to total } \\
\text { assets, measured at the end of the most recent fiscal } \\
\text { year before loan origination (Compustat). }\end{array}$ \\
\hline Tangibility & $\begin{array}{l}\text { The ratio of a borrower's net PPE to total assets, } \\
\text { measured at the end of the most recent fiscal year } \\
\text { before loan origination (Compustat). }\end{array}$ \\
\hline Credit Rating Availability & $\begin{array}{l}\text { An indicator variable equal to } 1 \text { if } \mathrm{S} \& \mathrm{P} \text { domestic } \\
\text { long-term issuer credit rating is available for a } \\
\text { borrower and } 0 \text { otherwise, measured at the end of the } \\
\text { most recent fiscal month before loan origination } \\
\text { (Compustat). }\end{array}$ \\
\hline \multicolumn{2}{|l|}{ Package-Level Variables } \\
\hline Lead Arranger Share & $\begin{array}{l}\text { The amount of loan taken by the lead arranger } \\
\text { divided by the total amount of the loan, calculated as } \\
\text { the average percentage of shares if there is more than } \\
\text { one lead arranger (Dealscan). }\end{array}$ \\
\hline Total PBR Share & $\begin{array}{l}\text { The amount of loan taken by all the participants with } \\
\text { a borrower relationship in the loan, divided by the } \\
\text { total amount of the loan (Dealscan). }\end{array}$ \\
\hline
\end{tabular}


Total PLR Share

Repeat Lead Arranger

Large Lead Arranger

Number of Lead Arrangers

Number of Participants

Facility-Level Variables

Loan Spread

Upfront Fee

Loan Maturity

Secured Loan

Facility Size
The amount of loan taken by all the participants with a lead arranger relationship in the loan, divided by the total amount of the loan (Dealscan).

An indicator variable equal to 1 if the lead arranger has lent to the borrower within 5 years, and 0 otherwise (Dealscan).

An indicator variable equal to 1 if the lead arranger is among the top 5 lead arrangers in terms of syndicated loan market share the year before loan origination, and 0 otherwise (Dealscan).

The number of lead arrangers in a loan package (Dealscan).

The number of participants in a loan package (Dealscan).

The amount a borrower pays in basis points over LIBOR for each dollar drawn down including any annual fees (Dealscan).

The one-time fee paid by the borrower to lenders at loan initiation (Dealscan).

The number of months a facility will be active from signing date to expiration date (Dealscan).

An indicator variable equal to 1 if a facility is secured and 0 otherwise (Dealscan).

The actual amount of the facility in millions committed by the facility's lender pool (Dealscan). 


\section{Appendix B: The Robustness Test on Total Participant Share}

\begin{tabular}{|c|c|}
\hline & $\begin{array}{c}\text { Dependent Variable } \\
\text { Total Participant share }\end{array}$ \\
\hline Borrower Size & $\begin{array}{c}1.470 * * * \\
(0.276)\end{array}$ \\
\hline Profitability & $\begin{array}{c}11.299 * * * \\
(2.738)\end{array}$ \\
\hline Leverage & $\begin{array}{l}-0.847 \\
(1.347)\end{array}$ \\
\hline Tangibility & $\begin{array}{c}1.997 \\
(1.378)\end{array}$ \\
\hline Credit Rating Availability & $\begin{array}{l}0.892 * \\
(0.502)\end{array}$ \\
\hline Lead Arranger Share & $\begin{array}{l}-0.749 \\
(0.496)\end{array}$ \\
\hline Repeat Lead Arranger & $\begin{array}{c}2.426 * * * \\
(0.380)\end{array}$ \\
\hline Large Lead Arranger & $\begin{array}{c}-0.048 \\
(0.402)\end{array}$ \\
\hline Number of Lead Arrangers & $\begin{array}{c}-5.022 * * * \\
(0.297)\end{array}$ \\
\hline Number of Participants & $\begin{array}{c}0.956 * * * \\
(0.061)\end{array}$ \\
\hline Constant & $\begin{array}{c}59.814 * * * \\
(2.265)\end{array}$ \\
\hline Industry Fixed Effect & Yes \\
\hline Year Fixed Effect & Yes \\
\hline $\begin{array}{l}\text { Observations } \\
\text { R-squared }\end{array}$ & $\begin{array}{l}5,989 \\
0.497 \\
\end{array}$ \\
\hline
\end{tabular}


Appendix C: The Robustness Test on PBR and PLR Measured by Outstanding Loans

\begin{tabular}{lc}
\hline & Dependent Variable \\
& Participant share \\
\hline & $0.609^{* * *}$ \\
Outstanding PBR & $(0.049)$ \\
& $0.603^{* * *}$ \\
Outstanding PLR & $(0.077)$ \\
& 0.093 \\
Industry Exposure & $(0.057)$ \\
& $0.117^{* *}$ \\
Lender Type & $(0.059)$ \\
& $-0.392^{* * *}$ \\
Borrower Size & $(0.149)$ \\
& $-1.671^{*}$ \\
Profitability & $(0.955)$ \\
& -0.682 \\
Leverage & $(0.559)$ \\
& $1.478^{* *}$ \\
Tangibility & $(0.744)$ \\
& $-0.538^{* * *}$ \\
Credit Rating Availability & $(0.152)$ \\
& $0.108^{* * *}$ \\
Lead Arranger Share & $(0.012)$ \\
& -0.046 \\
Repeat Lead Arranger & $(0.088)$ \\
Large Lead Arranger & $-0.424^{* * *}$ \\
& $(0.112)$ \\
Number of Lead Arrangers & $-0.966^{* * *}$ \\
Number of Participants & $(0.102)$ \\
Constant & $-0.181^{* * *}$ \\
Borrower Fixed Effect & $(0.018)$ \\
Year Fixed Effect & $14.410^{* * *}$ \\
R-squared & $(1.241)$ \\
& $Y e s$ \\
& $Y e s$ \\
& 61,373 \\
& 0.666 \\
\hline & \\
& \\
& \\
&
\end{tabular}




\begin{tabular}{|c|c|}
\hline & $\begin{array}{c}\text { Dependent Variable } \\
\text { Participant share }\end{array}$ \\
\hline$P B R$ & $\begin{array}{c}0.713 * * * \\
(0.156)\end{array}$ \\
\hline$P L R$ & $\begin{array}{c}0.645^{* * *} * \\
(0.086)\end{array}$ \\
\hline$P B R * P L R$ & $\begin{array}{c}-0.050 \\
(0.154)\end{array}$ \\
\hline Industry Exposure & $\begin{array}{c}0.072 \\
(0.057)\end{array}$ \\
\hline Lender Type & $\begin{array}{l}0.098 * \\
(0.059)\end{array}$ \\
\hline Borrower Size & $\begin{array}{c}-0.395 * * * \\
(0.149)\end{array}$ \\
\hline Profitability & $\begin{array}{c}-1.722^{*} \\
(0.956)\end{array}$ \\
\hline Leverage & $\begin{array}{c}-0.691 \\
(0.558)\end{array}$ \\
\hline Tangibility & $\begin{array}{c}1.488 * * \\
(0.743)\end{array}$ \\
\hline Credit Rating Availability & $\begin{array}{c}-0.538 * * * \\
(0.153)\end{array}$ \\
\hline Lead Arranger Share & $\begin{array}{c}0.108 * * * \\
(0.012)\end{array}$ \\
\hline Repeat Lead Arranger & $\begin{array}{c}-0.071 \\
(0.088)\end{array}$ \\
\hline Large Lead Arranger & $\begin{array}{c}-0.426 * * * \\
(0.111)\end{array}$ \\
\hline Number of Lead Arrangers & $\begin{array}{c}-0.966 * * * \\
(0.102)\end{array}$ \\
\hline Number of Participants & $\begin{array}{c}-0.180 * * * \\
(0.018)\end{array}$ \\
\hline Constant & $\begin{array}{c}14.405 * * * \\
(1.237)\end{array}$ \\
\hline Borrower Fixed Effect & Yes \\
\hline Year Fixed Effect & Yes \\
\hline Observations & 61,373 \\
\hline R-squared & 0.666 \\
\hline
\end{tabular}


Appendix E: The Robustness Test on Relationship Intensity

\begin{tabular}{lc}
\hline & Dependent Variable \\
& Participant share \\
\hline & $0.276^{* * *}$ \\
PBR Intensity & $(0.023)$ \\
& $0.003^{* * *}$ \\
PLR Intensity & $(0.000)$ \\
Industry Exposure & $0.141^{* *}$ \\
& $(0.057)$ \\
Lender Type & 0.014 \\
& $(0.060)$ \\
Borrower Size & $-0.406^{* * *}$ \\
& $(0.147)$ \\
Profitability & $-1.650^{*}$ \\
& $(0.947)$ \\
Leverage & -0.668 \\
& $(0.556)$ \\
Tangibility & $1.585^{* *}$ \\
Credit Rating Availability & $(0.732)$ \\
& $-0.524^{* * *}$ \\
Lead Arranger Share & $(0.153)$ \\
& $0.107^{* * *}$ \\
Repeat Lead Arranger & $(0.012)$ \\
Large Lead Arranger & -0.001 \\
& $(0.088)$ \\
Number of Lead Arrangers & $-0.495^{* * *}$ \\
Number of Participants & $(0.114)$ \\
Constant & $-0.970^{* * *}$ \\
Borrower Fixed Effect & $(0.102)$ \\
Year Fixed Effect & $-0.179^{* * *}$ \\
R-squared & $(0.018)$ \\
& $15.067^{* * *}$ \\
& $(1.219)$ \\
$Y e s$ \\
& $Y e s$ \\
& 61,373 \\
& 0.667 \\
\hline
\end{tabular}


Appendix F: The Robustness Test on Single Facility Loans

\begin{tabular}{lc}
\hline & $\begin{array}{c}\text { Dependent variable } \\
\text { Participant Share }\end{array}$ \\
\hline PBR & $0.595^{* * *}$ \\
& $(0.057)$ \\
PLR & $0.690^{* * *}$ \\
& $(0.105)$ \\
Industry Exposure & 0.094 \\
& $(0.068)$ \\
Lender Type & 0.077 \\
& $(0.067)$ \\
Borrower Size & $-0.310^{*}$ \\
Profitability & $(0.183)$ \\
& -1.019 \\
Leverage & $(1.317)$ \\
& -0.770 \\
Tangibility & $(0.730)$ \\
& 0.813 \\
Credit Rating Availability & $(0.830)$ \\
& $-0.501^{* * *}$ \\
Lead Arranger Share & $(0.186)$ \\
& $0.133^{* * *}$ \\
Repeat Lead Arranger & $(0.014)$ \\
& -0.078 \\
Large Lead Arranger & $(0.095)$ \\
Number of Lead Arrangers & $-0.299^{* * *}$ \\
Number of Participants & $(0.113)$ \\
& $-1.215^{* * *}$ \\
Loan Maturity & $(0.125)$ \\
Secured Loan & $-0.207^{* * *}$ \\
Facility Size & $(0.028)$ \\
Loan Spread & $-0.012^{* * *}$ \\
Constant & $(0.004)$ \\
Borrower Fixed Effect & 0.032 \\
Year Fixed Effect & $(0.185)$ \\
R-squared & $0.000^{*}$ \\
& $(0.000)$ \\
& 0.000 \\
& $(0.001)$ \\
& $15.283^{* * *}$ \\
& $(1.647)$ \\
Yes & Yes \\
& 43,829 \\
& 0.685 \\
\hline
\end{tabular}




\section{Appendix G: PSM Robustness Tests}

\begin{tabular}{|c|c|c|}
\hline & $\begin{array}{c}\text { (1) } \\
\text { PSM_PBR }\end{array}$ & $\begin{array}{c}(2) \\
\text { PSM_PLR }\end{array}$ \\
\hline$P B R$ & $\begin{array}{c}0.723 * * * \\
(0.057)\end{array}$ & $\begin{array}{c}0.427 * * * \\
(0.156)\end{array}$ \\
\hline$P L R$ & $\begin{array}{c}0.321 * * \\
(0.146)\end{array}$ & $\begin{array}{c}0.501 * * * \\
(0.147)\end{array}$ \\
\hline Industry Exposure & $\begin{array}{l}-0.009 \\
(0.070)\end{array}$ & $\begin{array}{l}-0.235 \\
(0.145)\end{array}$ \\
\hline Lender Type & $\begin{array}{c}0.168 * * \\
(0.075)\end{array}$ & $\begin{array}{c}0.062 \\
(0.136)\end{array}$ \\
\hline Borrower Size & $\begin{array}{l}-0.202 \\
(0.146)\end{array}$ & $\begin{array}{c}0.395 \\
(0.442)\end{array}$ \\
\hline Profitability & $\begin{array}{l}-0.013 \\
(1.140)\end{array}$ & $\begin{array}{l}-0.304 \\
(1.852)\end{array}$ \\
\hline Leverage & $\begin{array}{l}-0.615 \\
(0.668)\end{array}$ & $\begin{array}{l}-2.329 \\
(1.787)\end{array}$ \\
\hline Tangibility & $\begin{array}{c}1.208 \\
(0.862)\end{array}$ & $\begin{array}{c}0.410 \\
(1.679)\end{array}$ \\
\hline Credit Rating Availability & $\begin{array}{c}-0.452 * * \\
(0.181)\end{array}$ & $\begin{array}{l}-0.240 \\
(0.281)\end{array}$ \\
\hline Lead Arranger Share & $\begin{array}{c}0.123 * * * \\
(0.013)\end{array}$ & $\begin{array}{c}0.132 * * * \\
(0.037)\end{array}$ \\
\hline Repeat Lead Arranger & $\begin{array}{l}-0.081 \\
(0.086)\end{array}$ & $\begin{array}{c}0.066 \\
(0.227)\end{array}$ \\
\hline Large Lead Arranger & $\begin{array}{c}-0.257 * * \\
(0.103)\end{array}$ & $\begin{array}{l}-0.345 \\
(0.220)\end{array}$ \\
\hline Number of Lead Arrangers & $\begin{array}{c}-1.099 * * * \\
(0.127)\end{array}$ & $\begin{array}{c}-1.286 * * * \\
(0.286)\end{array}$ \\
\hline Number of Participants & $\begin{array}{c}-0.171 * * * \\
(0.016)\end{array}$ & $\begin{array}{c}-0.240 * * * \\
(0.030)\end{array}$ \\
\hline Constant & $\begin{array}{c}12.698 * * * \\
(1.198)\end{array}$ & $\begin{array}{c}9.386 * * * \\
(2.777)\end{array}$ \\
\hline Borrower Fixed Effect & Yes & Yes \\
\hline Year Fixed Effect & Yes & Yes \\
\hline Observations & 48,134 & $88,826^{28}$ \\
\hline R-squared & 0.679 & 0.714 \\
\hline
\end{tabular}

\footnotetext{
${ }^{28}$ Since the mean of PLR $=0.84$, participants have more loans with PLR than without PLR. Therefore, the PSM matching process involves duplicate usage of the control sample ( $\mathrm{PLR}=0)$, and the number of observations $(88,826)$ is larger than that in the main regression in Table $2(61,373)$. However, I confirm that for a subsample of test loans (loans with PLR=1) without duplicate usage of the control loans (loans with PLR=0), the result still holds (coefficient on PLR $=0.295$, significant at $10 \%$ level).
} 